Article

\title{
Assessing Land Cover and Ecological Quality Changes in the Forest-Steppe Ecotone of the Greater Khingan Mountains, Northeast China, from Landsat and MODIS Observations from 2000 to 2018
}

\author{
Fang Shi ${ }^{1}$, Mingxing Liu ${ }^{2}$, Jie Qiu ${ }^{3}$, Yali Zhang ${ }^{1}$, Huiyi Su ${ }^{1}$, Xupeng Mao ${ }^{1}$, Xin Li ${ }^{1}$, Jiahui Fan ${ }^{4}$, Junsong Chen ${ }^{5}$ \\ Yingying $\mathrm{Lv}^{4}$, Wanggu $\mathrm{Xu}^{4}$, Zhi Wang ${ }^{4}$ and Mingshi Li ${ }^{1,6, *(D)}$ \\ 1 College of Forestry, Nanjing Forestry University, Nanjing 210037, China; shifang@njfu.edu.cn (F.S.); \\ nfuzy1128@njfu.edu.cn (Y.Z.); suhuiyi@njfu.edu.cn (H.S.); mxp@njfu.edu.cn (X.M.); \\ lixin@njfu.edu.cn (X.L.) \\ 2 Hunan Prospecting Designing \& Research General Institute for Agriculture Forestry \& Industry, \\ Changsha 410007, China; ybx0329@njfu.edu.cn \\ 3 Provincial Geomatics Center of Jiangsu, Nanjing 210013, China; rongyu19970116@njfu.edu.cn \\ 4 Nanjing Institute of Environmental Sciences (NIES), Ministry of Environmental Protection (MEP), \\ Nanjing 210042, China; nnnl@njfu.edu.cn (J.F.); lvyingying@nies.org (Y.L.); xuwanggu@nies.org (W.X.); \\ wangzhi@nies.org (Z.W.) \\ 5 Jiangxi Academy of Forestry, Nanchang 330032, China; sunbiao@njfu.edu.cn \\ 6 Co-Innovation Center for Sustainable Forestry in Southern China, Nanjing Forestry University, \\ Nanjing 210037, China \\ * Correspondence: nfulms@njfu.edu.cn
}

Citation: Shi, F.; Liu, M.; Qiu, J.; Zhang, Y.; Su, H.; Mao, X.; Li, X.; Fan, J.; Chen, J.; Lv, Y.; et al. Assessing Land Cover and Ecological Quality Changes in the Forest-Steppe Ecotone of the Greater Khingan Mountains, Northeast China, from Landsat and MODIS Observations from 2000 to 2018. Remote Sens. 2022, 14, 725 https://doi.org/10.3390/rs14030725

Academic Editor: John

F. Weishampel

Received: 20 December 2021

Accepted: 31 January 2022

Published: 3 February 2022

Publisher's Note: MDPI stays neutral with regard to jurisdictional claims in published maps and institutional affiliations.

Copyright: (c) 2022 by the authors. Licensee MDPI, Basel, Switzerland. This article is an open access article distributed under the terms and conditions of the Creative Commons Attribution (CC BY) license (https:// creativecommons.org/licenses/by/ $4.0 /)$.

\begin{abstract}
Land cover changes are the main factors driving the evolution of regional ecological quality. These changes must be considered in the strategic formulation of regional or national ecological policies. The forest-steppe ecotone in the Greater Khingan Mountains is an important ecological barrier in northern China. To measure the effect of ecological protection in recent years, Landsat images, object-oriented image segmentation, and convolutional neural networks were used to create land cover datasets of the forest-steppe ecotone. The Carnegie-Ames-Stanford approach (CASA) and the dimidiate pixel model were used to derive net primary productivity (NPP) and fractional vegetation cover (FVC) to assess the ecological quality of this area. The results showed that only grassland and urban land increased, whereas saline-alkali land and desert areas initially increased and then decreased from 2010 to 2018, indicating that the desertification process was substantially curbed. Total NPP increased by $26.3 \%$ (2000-2010) and 10.8\% (2010-2018). However, NPP decreased slightly in the center of the study area. FVC first decreased and then increased, and the increased areas were concentrated in the forest-steppe ecotone, saline-alkali land, and desert zone in Xin Barag Left Banner. These observations indicate that the ecological quality has gradually improved due to the strict protection of forest and grassland resources and the suppression of desertification. Our results provide potential insights for land use planning and the development of environmental protection measures in the forest-steppe ecotone.
\end{abstract}

Keywords: land cover conversion; ecological quality; net primary productivity; fractional vegetation cover; forest-steppe ecotone

\section{Introduction}

Land use/cover change (LUCC) is the main research direction of land change science and landscape ecology [1-4]. It is of great significance to protect land resources and improve the ecological environment [5]. Contemporary human activities are causing profound impacts on terrestrial ecosystems and landscape patterns, primarily by altering land use purposes, which reflects the manner and extent of human influence on the natural 
ecosystem [6]. Due to population growth and economic booms, the irrational exploitation of natural resources has become a primary cause contributing to environmental deterioration in both intensity and extent, including habitat loss and the degradation of ecosystem functions [7]. Thus, a quantitative assessment of ecological quality in an effective and timely manner helps identify the current regional status of sustainable development to enable the implementation of countermeasures to protect the eco-environment [8].

Globally, the most significant land cover change is the expansion of farmland and pastoral areas $[9,10]$. However, land cover change in China is more complex. Due to accelerated economic development, the urbanization rate in China has increased from $17.9 \%$ in 1978 to $49.7 \%$ in 2010, significantly increasing the expansion of urban areas [11]. In many developing regions of China, poor farmers are also turning forest/grassland into farmland to increase their income. In view of the negative impact of the unreasonable utilization of cultivated land on the ecological environment, the Chinese government implemented the Grain-for-Green policy in 1999 [12]. The forest-steppe ecotone of the Greater Khingan Mountains is a transitional area of forest to grassland ecosystems in this region, and an important ecological barrier. Conflict exists between the Grain-for-Green policy and the significant demand for food production. However, few studies have developed a consistent and accurate land cover change product spanning a long-term period in this particular ecotone, preventing a quality assessment of the eco-environment because existing ecotone studies have mostly focused on land degradation and environmental management in short-term periods [13-15], such as ten years. Hence, it is difficult to propose substantive suggestions for targeted ecological ecotone management based on existing findings. Thus, it is significant to create a consistent and fine-scale mapping product describing land cover and ecological quality change for a long-term period in the Greater Khingan Mountains.

A variety of land cover products with different spatial resolutions or spatial scales based on satellite remote sensing have been developed, including the $1 \mathrm{~km}$ spatial resolution IGBP DISCOVER 1996 product [16], the $1 \mathrm{~km}$ UMD Land Cover Classification 1992 [17], the $1 \mathrm{~km}$ resolution Global Land Cover 2000 [18], the $500 \mathrm{~m}$ MODIS land cover product [19], and the $300 \mathrm{~m}$ ESA Glob Cover 2005 product [20]. Although these products have successfully supported multiple scientific applications at national, continental, and global scales, they are not suitable for regional and local applications due to their coarse resolutions or high uncertainties in complex and fragmented landscapes. The $30 \mathrm{~m}$ resolution land cover products, for example, the National Land Cover Database (NLCD) 2016 product [21] and the Finer Resolution Observation and Monitoring of Global Land Cover (FROM-GLC) 2017 product [22], were developed to improve the utility of land cover products in scientific applications at regional and local scales. However, these relatively fine-resolution products are not conducive for use in a multitemporal dataset due to the computational complexity of mapping using remote sensing data, preventing dynamic assessments of ecological conditions and the environment at the regional scale [23].

The net primary productivity (NPP) of an ecosystem is an important component of the surface carbon cycle [24,25]. It reflects the productivity of vegetation communities under natural environmental conditions and the quality of terrestrial ecosystems. Fractional vegetation cover (FVC) is a crucial parameter to measure vegetation density and to estimate the photosynthetic area of vegetation communities, as well as an important indicator of environmental change [26]. NPP and FVC are considered indicators of ecological quality and are closely related to the local climate, soil, water resources, and land resources. Therefore, producing a consistent and fine-resolution land cover change product lays a solid foundation for assessing regional ecological quality.

Traditionally, ground-sampling surveys and fixed-point observations are used to estimate NPP and FVC. These measurements are difficult to obtain in large areas or at the regional scale due to cost and time constraints. Furthermore, the measurements do not reflect the continuous surface properties of NPP and FVC due to the discrete and limited number of samples. Thus, traditional ground-based observations may not be practical for ecosystem modeling and evaluating ecological quality over large areas. As 
a result, remote-sensing-based modeling methods have become mainstream to estimate NPP and FVC. Since 1990, numerous studies have been conducted to investigate NPP and FVC using remote-sensing-based modeling. For example, the Carnegie-Ames-Stanford approach (CASA) [27] and the C-FIX model [28] are two representative NPP models. The CASA model requires fewer input parameters than other models, reducing the error due to model simplification or a lack of parameters. The remote sensing data used by the CASA have a wide coverage and high temporal frequency, enabling the dynamic monitoring of regional and global NPP. Thus, the CASA model has been widely used in large-scale NPP and global carbon cycle research. Cao et al. (2020) researched the impacts of land conversion and management measures on NPP in semi-arid grasslands using the CASA model [29]. Bao et al. (2020) investigated changes in terrestrial NPP and climate constraints in Mongolia with the CASA model [30]. They developed a map of the relative contributions of the climatic constraints to NPP in 1982-2011.

Commonly used models to estimate FVC include empirical, vegetation index, and mixed pixel decomposition models. Empirical models strongly depend on the accuracy of ground-measured data and generally have a relatively low generalization ability [31-33]. Vegetation index models describe the relationship between a vegetation index and vegetation cover; however, most vegetation indices are influenced by non-vegetation features, such as soils. The mixed pixel decomposition model retrieves FVC by calculating the proportion of the classes in the mixed pixel. The dimidiate pixel model is a mixed pixel decomposition model that linearly decomposes the spectral signals of green vegetation and bare soil in each pixel to extract the vegetation abundance vegetation cover. This method minimizes the influence of background factors, including soil, and has been widely used for extracting FVC, providing excellent results. Wang et al. (2020) used the dimidiate pixel model to obtain FVC and the vegetation growth status in the Pisha sandstone area of China [34]. Li et al. (2020) analyzed the FVC response to climatic factors in the 2000-2017 growing season in Sichuan Province, China, using the dimidiate pixel model [35]. They found that the vegetation cover in Sichuan Province showed a slight degradation trend, and the medium- to low-elevation woody plants were significantly degraded.

The objectives of this study were to (1) assess the LUCC and ecological quality in the forest-steppe ecotone of the Greater Khingan Mountains using NPP and FVC, and (2) formulate comprehensive management measures to promote the sustainable management of landscapes in the forest-steppe ecotone. The research results are expected to provide an important scientific basis and suggestions for land use planning and environmental protection in the forest-steppe ecotone of the Greater Khingan Mountains.

\section{Materials and Methods}

\subsection{Study Area}

The study area was located in Hulunbuir city in the northeastern part of the Inner Mongolia Autonomous Region (Figure 1). Hulunbuir prairie and Hulun Lake are located in the western part of the study area, and the northwestern part borders Russia. The Greater Khingan Range containing the Hulunbuir forest area is oriented from the northeast to the southeast. The central part of the study area is the forest-steppe ecotone of the Greater Khingan Mountains ( $47^{\circ} 19^{\prime} 49^{\prime \prime}$ N-53 $20^{\prime} 01^{\prime \prime}$ N, 117 $31^{\prime} 28^{\prime \prime}$ E-122 $52^{\prime} 52^{\prime \prime}$ E), which contains seven banners (district and county-level cities), including Xin Barag Left Banner, Evenki Autonomous Banner, Hailar District, Prairie Chenbarhu Banner, Yakeshi City, Genhe City, and Ergun City. The area is $696 \mathrm{~km}$ long (north to south) and $384 \mathrm{~km}$ wide (east to west) (Figure 1). The average elevation of this area is $573 \mathrm{~m}$, and the average annual precipitation is $250-350 \mathrm{~mm}$. The precipitation amount decreases from east to west. Hulunbuir is located in the northern temperate climate zone with a distinctly continental climate, characterized by long, cold winters, short warm summers, strong dry winds in spring, sharp drops in autumn temperatures, and early frosts. Most precipitation falls in July and August. 


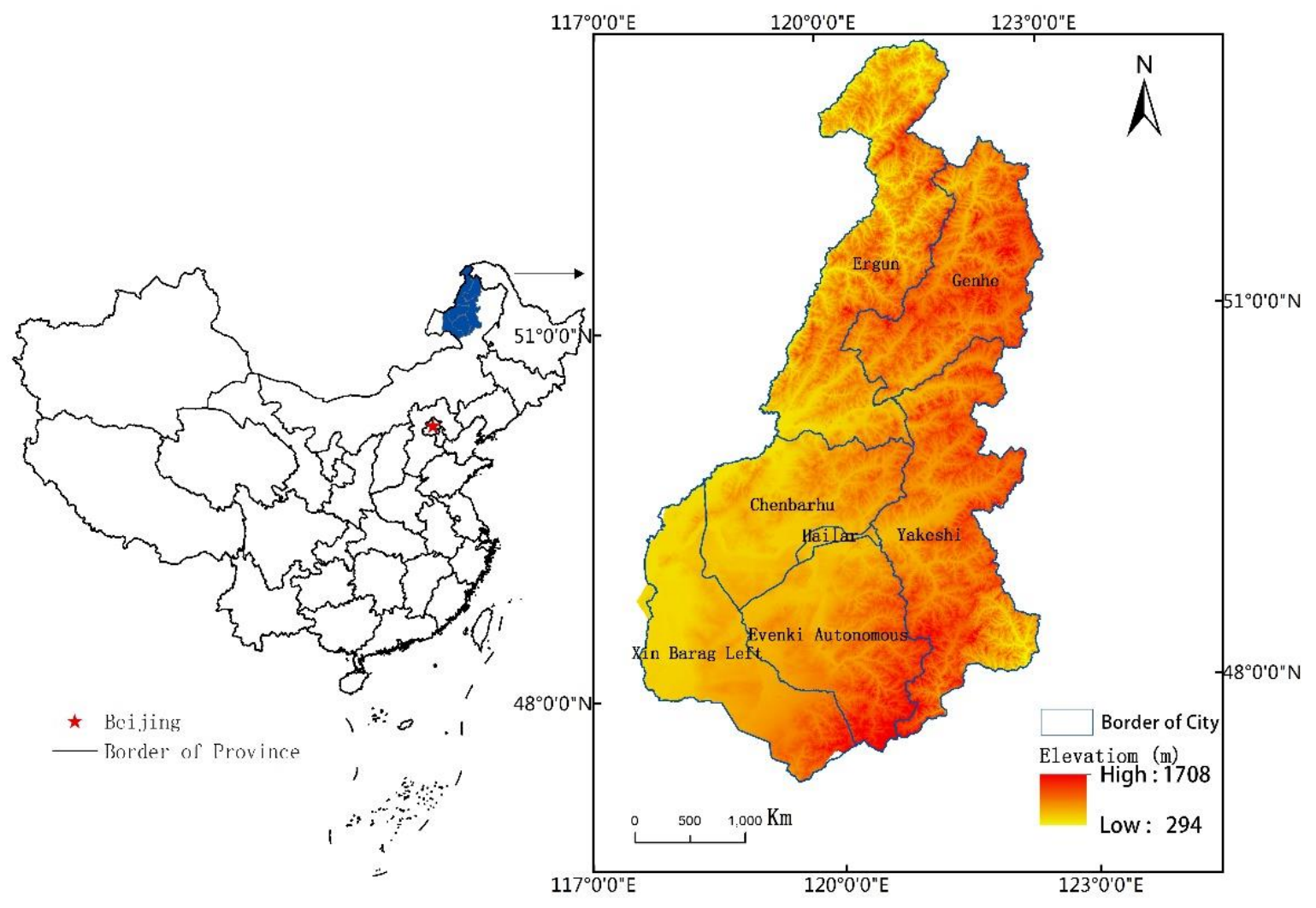

Figure 1. Location of the study area.

\subsection{Data Sources and Preprocessing}

The data sources included remote sensing image data, meteorological data, and field survey data. Fifty Landsat 5 TM scenes acquired in 2000 and 2010, and Landsat 8 OLI scenes acquired in 2018 were obtained from the USGS official website (https: / glovis.usgs.gov/, 14 July 2019). The images were geometrically and atmospherically corrected by the USGS EROS data center using the Landsat Ecosystem Disturbance Adaptive Processing System (LEDAPS) in batch mode or the Landsat 8 Surface Reflectance Code (LaSRC) per customer request when placing orders. The Landsat surface reflectance images with high geometric and radiometric accuracies were downloaded from the USGS EROS Center Science Processing Architecture (ESPA) (https: / / espa.cr.usgs.gov/, 16 July 2019) to develop the land cover and FVC products. We verified the accuracies of these products using visual interpretations of Google Earth images in the same period. Most images acquired in the growing season had no or few clouds. The field survey data of the land cover type were used to train and validate the land cover classification models, and forest sample plot inventory data were used to validate the NPP modeling results.

MODIS (MOD13Q1, MOD17A2H) data acquired in 2000, 2010, and 2018 were obtained from the MODIS website (https: / / search.earthdata.nasa.gov/, 26 August 2019). Normalized difference vegetation index (NDVI) products derived from MODIS data were used for the NPP estimations. The meteorological data used to calculate NPP included average monthly temperature, total monthly solar radiation, and total monthly precipitation obtained from 22 meteorological stations in and around the Greater Khingan Mountains. The data were downloaded from the China Meteorological Data Network (http:/ / data.cma.cn/, 28 August 2019).

\subsection{Land Cover Classification Scheme}

We used the National Land Classification System to determine seven land cover types in the Greater Khingan Mountains: forest, grassland, farmland, wetland, urban land, desert, and burned land [36]. Forest included coniferous forest, broad-leaved forest, and mixed 
forest. Grassland included pasture, meadow, and tussock areas. Farmland included paddy fields and dry land. Wetland included lakes, reservoirs, rivers, shrub wetlands, arbor wetlands, and herb wetlands. Urban land included construction land, transportation, and mining areas. Desert areas included bare rock, Gobi Desert, bare soil, saline-alkali land, and glaciers. Burned land referred to areas with recent wildfires.

\subsection{Land Cover Classification}

Unlike traditional machine learning algorithms, deep learning methods do not require the manual extraction of regions of interest (ROIs) and need fewer preprocessing steps before model construction, improving efficiency. Convolutional neural networks (CNNs) have commonly been used in recent years due to their outstanding performance for image recognition [37-39]. The AlexNet network model designed by Hinton and Krizhevsky is not the first CNN model, but it has attracted much attention because it won first prize in the Image Net Large Scale Visual Recognition Competition (ILSVRC) [40]. AlexNet is the preferred network model due to its high robustness and continuous improvement and optimization [41]. Thus, this study used the CNN model AlexNet trained on the ImageNet dataset for land cover classifications. Its network structure is shown in Figure 2.
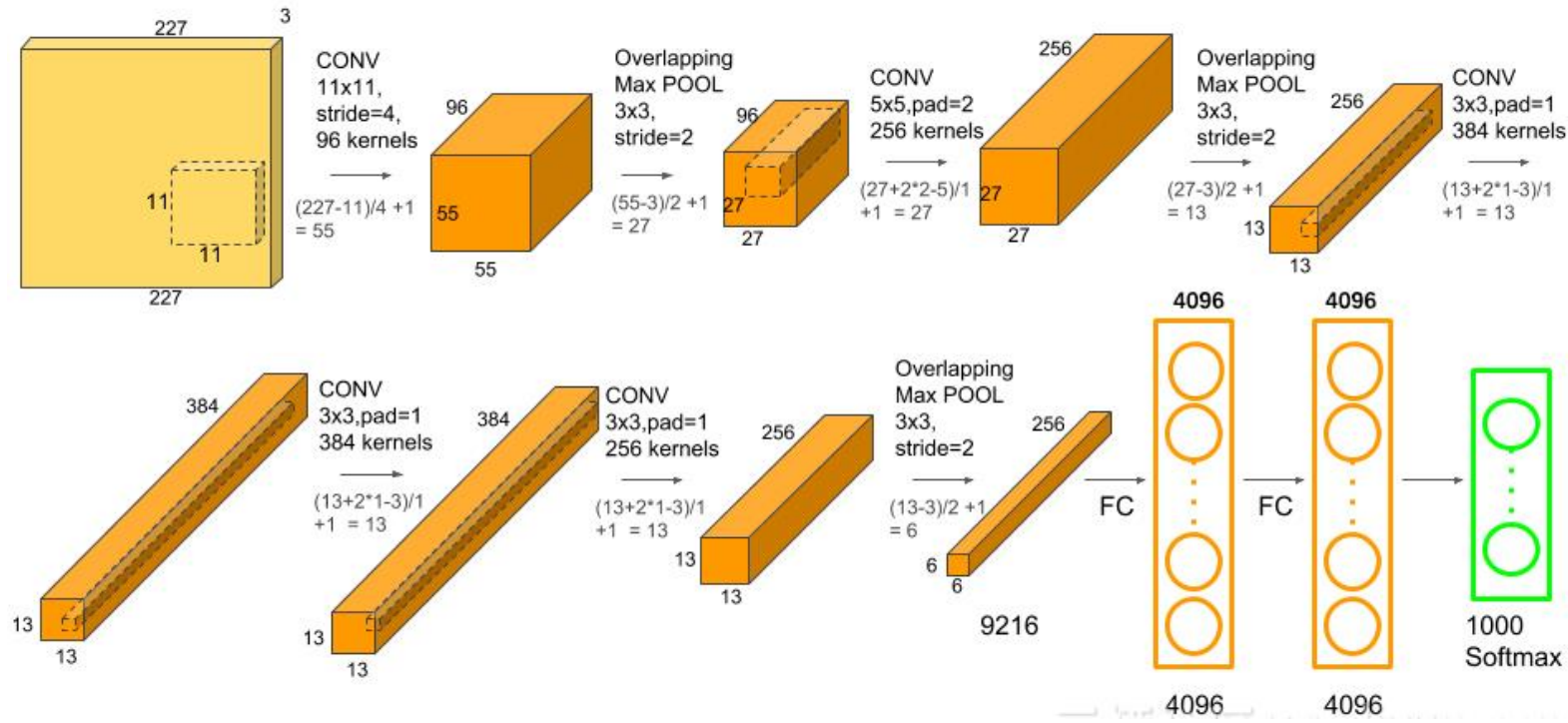

Figure 2. AlexNet network structure.

\subsubsection{Preprocessing}

We used the multiscale segmentation method in the eCognition software to segment the images of the study area [42]. The scale parameter was 400, the shape index was 0.1 , and the compactness was 0.5. Sample patches of different land cover types were selected as training samples from the segmented image for land cover classification. Then, the land cover image was resized to match the input size of the CNN model for pretraining. Subsequently, the land cover image dataset was normalized to the same format.

\subsubsection{Model Training}

The network model had 8 weighted layers, including 5 convolutional layers and 3 fully connected layers. The convolutional layer consisted of a rectified linear unit (ReLU) layer, a normalization layer, and a max-pooling layer. The preprocessed image was used as the input layer of the model. After the convolution kernel was applied to the image, the network training speed was accelerated using the ReLU activation function in the convolution layer. Max pooling was used, and a dropout function was utilized to disable $50 \%$ of the network nodes in the fully connected layer to prevent overfitting of the algorithm. 
Finally, the network parameters were fine-tuned, and the Softmax classifier was used to classify the output of the connection layer [43].

\subsubsection{Fine-Tuning AlexNet}

The most commonly used fine-tuning step consists of updating the weights of a trained model with a specific dataset with similar characteristics to ensure that the adjusted network model is applicable to the dataset. We used Chen's method (2019) for fine-tuning [43]. The dataset was relatively small; therefore, training the classifier from the top of the network would have contained too many characteristics, leading to classification errors [44]. Thus, the classifier was trained starting from the activation function to achieve good results.

The AlexNet model was initially trained on ImageNet. The ImageNet dataset contains approximately $1 \times 10^{6}$ natural images and 1000 categories (labels). However, the land cover dataset in this study contained only 7 categories (labels). Thus, the land cover dataset in this study was not sufficient to train the AlexNet network with a complex structure. Thus, according to the weights of the AlexNet network trained by ImageNet, the classification layer that originally output 1000 categories was adjusted to the 7 categories in Figure 3 , including forest, grassland, farmland, wetland, urban land, desert, and burned land.
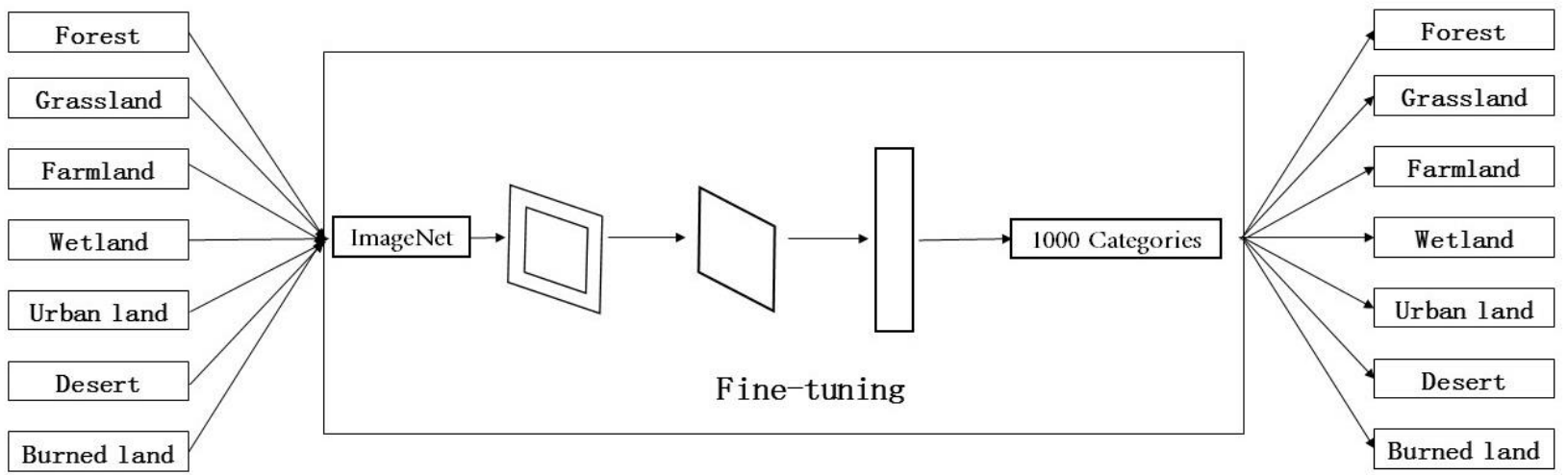

Figure 3. Fine-tuning strategy.

\subsection{Estimation of NPP}

NPP refers to the amount of organic matter accumulated by green plants per unit area and unit time $[45,46]$. It represents the gross primary productivity, i.e., the organic carbon fixed by photosynthesis minus plant respiration. NPP plays an important role in global change and the carbon balance. The CASA model, which describes the NPP mechanism based on plant physiology, is a popular NPP model [47], and has been widely used for NPP simulation in different regions and at different scales [48]. NPP is expressed by two factors in the CASA model: photosynthetically active radiation absorbed by plants and light energy utilization efficiency. The equation is as follows:

$$
\operatorname{NPP}(x, t)=\operatorname{APAR}(x, t) * \varepsilon(x, t)
$$

where $\operatorname{APAR}(x, t)$ is the photosynthetically active radiation absorbed by an area (pixel) $x$ in month $t\left(\mathrm{MJ} \cdot \mathrm{m}^{-2} \cdot\right.$ month $\left.^{-1}\right)$, and $\varepsilon(x, t)$ is the light energy utilization rate of pixel $x$ in month $t\left(\mathrm{gC} \cdot \mathrm{MJ}^{-1}\right)$.

The photosynthetically active radiation absorbed by plants depends on the total solar radiation and the solar radiation absorbed by plants. It is expressed as follows:

$$
\operatorname{APAR}(x, t)=\operatorname{SOL}(x, t) * \operatorname{FPAR}(x, t) * 0.5
$$

where $\operatorname{SOL}(x, t)$ represents the total solar radiation in pixel $x$ in month $t\left(\mathrm{MJ} \cdot \mathrm{m}^{-2} \cdot \mathrm{month}^{-1}\right)$, and the constant 0.5 indicates the ratio of effective solar radiation to total solar radiation. 
$\operatorname{FPAR}(x, t)$ is the absorption ratio of the vegetation layer to the incident photosynthetically active radiation. It can be calculated as follows:

$$
\operatorname{FPAR}(x, t)=\alpha F P A R_{N D V I} *(1-\alpha) F P A R_{S R}
$$

where $\alpha$ is the adjustment coefficient between the two methods, FPAR ${ }_{N D V I}$ is the FPAR estimated by $N D V I$, and FPAR $R_{S R}$ is the FPAR estimated by the simple ratio vegetation index $(S R)$.

Under ideal conditions, vegetation has the maximum light energy utilization rate. Under realistic conditions, the maximum light energy utilization rate is primarily affected by temperature and moisture, which can be expressed by the following equation:

$$
\varepsilon(x, t)=T_{\varepsilon 1}(x, t) * T_{\varepsilon 2}(x, t) * W_{\mathcal{\varepsilon}}(x, t) * \varepsilon_{\max }
$$

where $T_{\varepsilon 1}(x, t)$ and $T_{\varepsilon 2}(x, t)$ indicate the stress effect of low temperature and high temperature on light energy utilization efficiency, respectively. $W_{\mathcal{\varepsilon}}(x, t)$ is the influence coefficient of water stress, reflecting the influence of water conditions. $\varepsilon_{\max }$ is the maximum light energy utilization under ideal conditions $\left(\mathrm{gC} \cdot \mathrm{MJ}^{-1}\right)$. In this study, the maximum light energy utilization used the parameter values proposed by Zhu et al. (2006) [49].

\subsection{Estimation of FVC}

FVC is defined as the percentage of the vertically projected area of vegetation on the ground to the total area [50,51]. It is a crucial parameter in climate, hydrology, and soil research [52]. In this study, the dimidiate pixel model was used to extract the FVC in the study area. The dimidiate pixel model assumes that a pixel is composed of vegetation and non-vegetation [53]. The FVC is expressed as follows:

$$
\mathrm{FVC}=\left(\mathrm{S}-\mathrm{S}_{\text {soil }}\right) /\left(\mathrm{S}_{\text {veg }}-\mathrm{S}_{\text {soil }}\right)
$$

where $S$ is the spectral response of the remote sensing data and $S_{v e g}$ and $S_{\text {soil }}$ are the spectral responses for a pure vegetation pixel and a pure soil pixel, respectively.

The NDVI is the most commonly used indicator of vegetation growth and has frequently been used in the dimidiate pixel model as the spectral response of remote sensing data to calculate FVC. Thus, the FVC equation was revised as follows:

$$
\mathrm{FVC}=\left(\mathrm{NDVI}-\mathrm{NDVI}_{\text {soil }}\right) /\left(\mathrm{NDVI}_{\text {veg }}-\mathrm{NDVI}_{\text {soil }}\right)
$$

where $\mathrm{NDVI}_{\text {soil }}$ represents the NDVI values of the nonvegetated or bare pixels, and $\mathrm{NDVI}_{\text {veg }}$ represents the NDVI values of vegetated pixels.

Theoretically, the value of $\mathrm{NDVI}_{\text {soil }}$ is close to 0 , and the value of $\mathrm{NDVI}_{\text {veg }}$ is close to $1 . \mathrm{NDVI}_{\text {soil }}$ is the minimum value of the NDVI; therefore, it is expressed as $\mathrm{NDVI}_{\text {min }}$. $\mathrm{NDVI}_{\text {veg }}$ is the maximum value of NDVI and is expressed as $\mathrm{NDVI}_{\text {max }}$ [23]. Remote sensing images are typically affected by noise; thus, the minimum and maximum values of the NDVI correspond to the confidence range that should be selected according to the specific conditions. In this study, the NDVI values corresponding to the $1 \%$ and $99 \%$ percentiles in the NDVI cumulative distribution were used as $\mathrm{NDVI}_{\min }$ and $\mathrm{NDVI}_{\text {max }}$, respectively, for calculating FVC to minimize the influence of noise.

\subsection{Verification Method}

In this study, 1000 random sample points (Figure 4) were generated in ArcGIS 10.8 to validate the accuracy of the three-phase land cover classification maps. We visually interpreted the land cover type of the 1000 points using temporally corresponding, highspatial-resolution Google Earth images. The results and the classification results generated from the AlexNet model were used to create confusion matrices showing the overall accuracy, producer's accuracy, user's accuracy, and Kappa coefficient. For the FVC validation, we chose 20 random verification windows $(90 \mathrm{~m} \times 90 \mathrm{~m}$ ) (Figure 4 ) and compared the ex- 
tracted vegetation cover with the visually interpreted results of the high-resolution Google Earth images. For the NPP validation, we randomly selected 200 points (Figure 4) and performed a linear regression analysis between the CASA model results and MODIS NPP product values. Figure 5 shows the workflow of the whole study.

\section{Legend}

- validation windows of FVC
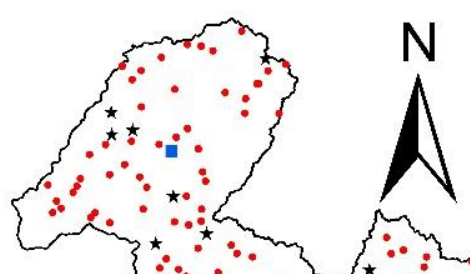

* validation points of NPP

- validation points of LC maps

$\square$ study area
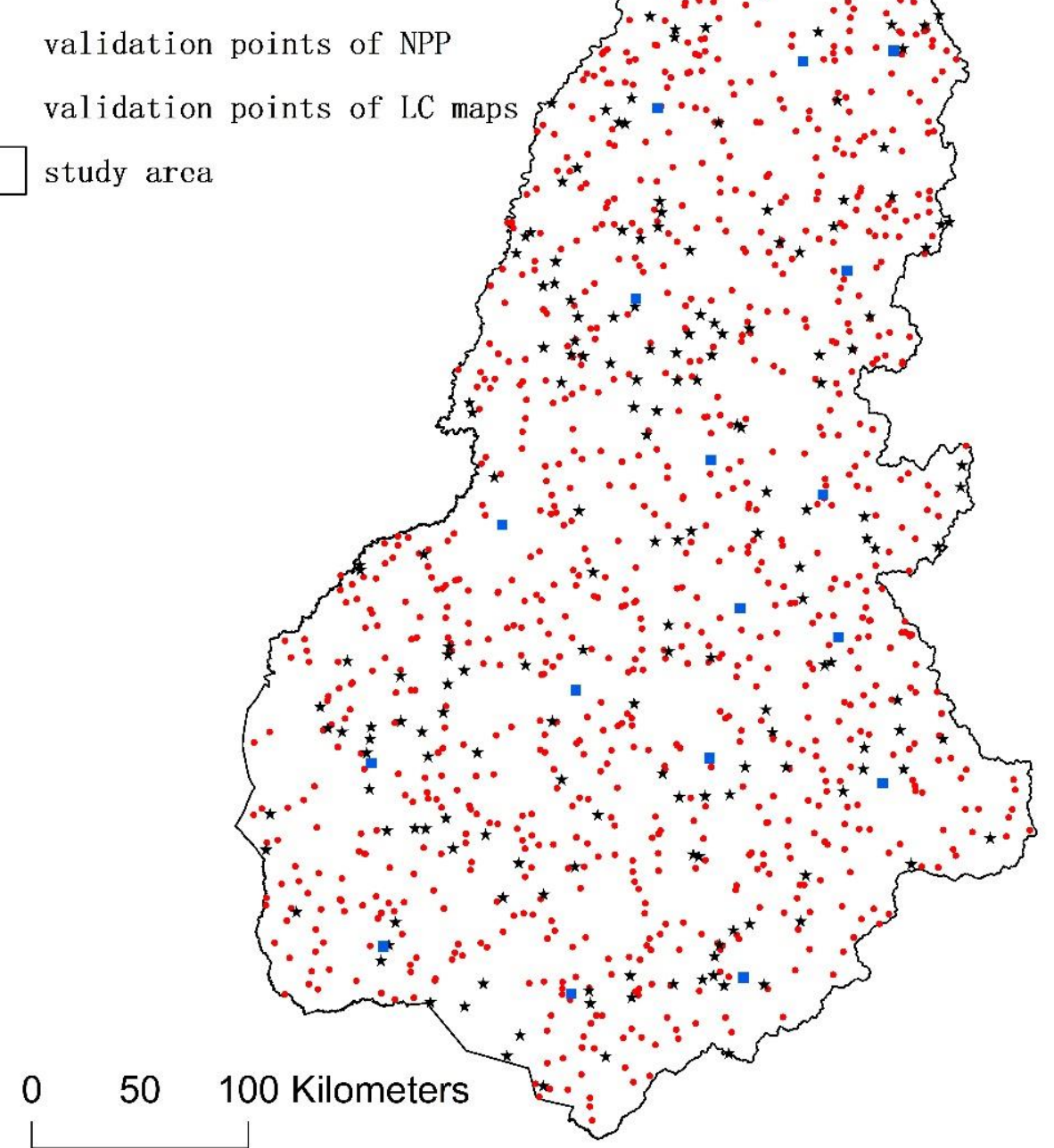

Figure 4. Validation points for the land cover classification maps and NPP and the validation windows for the FVC. 


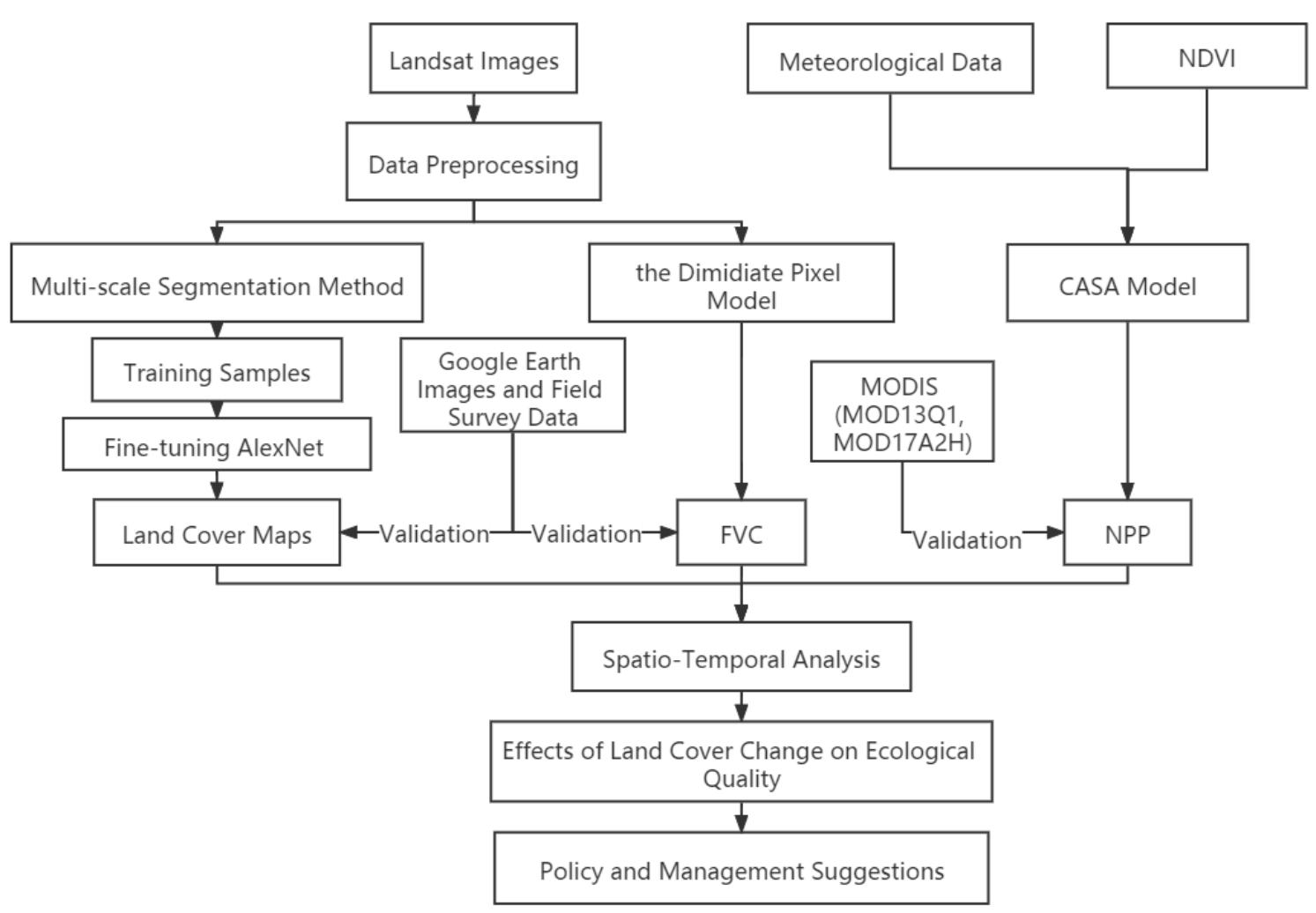

Figure 5. The technique workflow.

\section{Results}

\subsection{Accuracy Assessment}

The overall accuracies of the 2000, 2010, and 2018 land cover classification maps were $93.5 \%, 93.4 \%$, and $90.4 \%$, with Kappa coefficients of $0.9198,0.9185$, and 0.8816 , respectively (Tables A1-A3). Overall, the classification accuracies of the three maps were satisfactory at the regional scale, and the classification results could be used to support subsequent analyses. Similarly, based on the 20 validation windows, the accuracies of the FVC were $87.23 \%$ in 2000, 88.47\% in 2010, and 91.74\% in 2018 (Tables A4-A6). Finally, the determination coefficients of the linear regression between the NPP obtained from the model and the MODIS NPP were 0.66 in 2000, 0.57 in 2010, and 0.60 in 2018 (Figures A1-A3). These results indicated a relatively moderate agreement, confirming that NPP could be used as an indicator to reflect the ecological quality of the study region.

\subsection{Land Cover Changes}

\subsubsection{Land Cover Classification Maps}

As shown in Figure 6, most forestland was located in the northern and eastern regions of the study area, i.e., in the Ergun, Genhe, and Yakeshi regions. Most grassland was located in the western and central parts of this region, including the Chenbarhu Banner, Evenki Autonomous Banner, Xin Barag Left Banner, and southern Ergun region. Farmland mainly lies in the transitional area between grassland and forest. It is closely related to human activities in the towns and the surrounding river systems. Most farmland was in the central part of the study area, including Hailar District, the central and western part of Yakeshi, the southern part of Ergun, the eastern part of Chenbarhu Banner, the northern part of Evenki Autonomous Banner, and the southeastern part of Xin Barag Left Banner. The remaining small areas of farmland were scattered along the wetland in the southeastern and northern parts of Yakeshi and along the central and western part of Ergun. Wetlands were found in all administrative regions and concentrated in the main river basins in the forest and grassland areas. The size of cities and towns in the study area was relatively small, and they were scattered. Most were located in the surrounding counties, including the Hailar 
District, Chenbarhu Banner, Evenki Autonomous Banner, and Yakeshi regions. Some towns were located southwest of the Ergun and Genhe regions. In addition, most roads were found near towns. The roads were scattered throughout the study area, indicating a sparse network. Roads are important for the economy in the forest-steppe ecotone. Desert areas were primarily located in Xin Barag Left Banner and Chenbarhu Banner. Burned land was present in the woodlands of Ergun and Genhe.

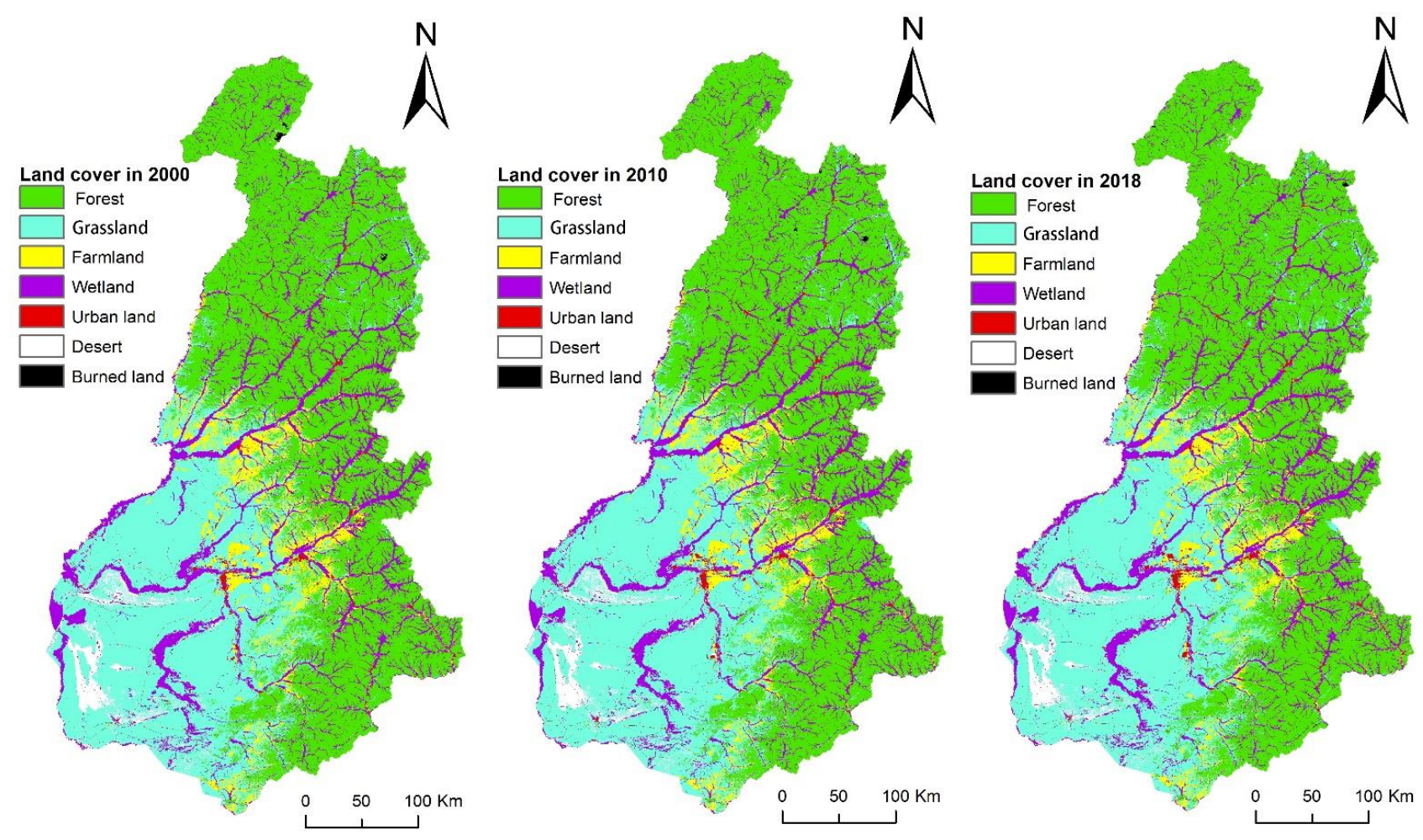

Figure 6. Land cover change in the forest-steppe ecotone of the Greater Khingan Mountains from 2000 to 2018.

Table 1 displays the statistics of the mapped land cover types in 2000-2018. Forest, grassland, and wetland accounted for more than $90 \%$ of the total area in all years. Specifically, the areal proportions of forestland, grassland, farmland, wetland, urban land, desert, and burned land were $46.96 \%, 31.33 \%, 5.17 \%, 13.29 \%, 1.11 \%, 2.07 \%$, and $0.07 \%$, respectively, in 2000 . By 2018 , the forest area had decreased by $0.14 \%$, grassland had increased by $0.24 \%$, farmland had decreased by $0.19 \%$, wetland had decreased by $0.1 \%$, and urban land had increased by $0.24 \%$. Interestingly, desert areas first increased and then decreased, showing a downward trend since 2010. Burned areas occupied a very small area and showed a decreasing trend over time, indicating effective forest fire prevention and suppression.

Table 1. Changes in the area and proportion of land cover types from 2000 to 2018.

\begin{tabular}{|c|c|c|c|c|c|c|}
\hline \multirow{2}{*}{ Types } & \multicolumn{2}{|c|}{2000} & \multicolumn{2}{|c|}{2010} & \multicolumn{2}{|c|}{2018} \\
\hline & Area $\left(\mathrm{hm}^{2}\right)$ & Proportion & Area $\left(\mathrm{hm}^{2}\right)$ & Proportion & Area $\left(\mathrm{hm}^{2}\right)$ & Proportion \\
\hline Forest & $6,302,993.31$ & $46.96 \%$ & $6,289,026.12$ & $46.85 \%$ & $6,284,566.53$ & $46.82 \%$ \\
\hline Grassland & $4,205,763.9$ & $31.33 \%$ & $4,233,760.38$ & $31.54 \%$ & $4,237,231.05$ & $31.57 \%$ \\
\hline Farmland & $693,927.63$ & $5.17 \%$ & $671,471.73$ & $5.00 \%$ & $667,805.49$ & $4.98 \%$ \\
\hline Wetland & $1,783,646.19$ & $13.29 \%$ & $1,770,893.19$ & $13.19 \%$ & $1,769,975.55$ & $13.19 \%$ \\
\hline Urban land & $148,534.83$ & $1.11 \%$ & $170,261.55$ & $1.27 \%$ & $180,543.42$ & $1.35 \%$ \\
\hline Desert & $278,190.27$ & $2.07 \%$ & $281,807.19$ & $2.10 \%$ & $280,257.48$ & $2.09 \%$ \\
\hline Burned land & 9397.53 & $0.07 \%$ & 5233.5 & $0.04 \%$ & 2074.14 & $0.02 \%$ \\
\hline
\end{tabular}




\subsubsection{Analysis of Land Cover Conversions}

Tables $2-4$ show the land cover transition matrices between the two dates. Figures 7 and 8 show the specific land cover conversion maps. Figure 9 shows an exemplary area on the comparison of the land cover change results and RGB ortho-mosaic images. From 2000 to 2018 (Table 2), $18856.17 \mathrm{hm}^{2}$ of forestland was converted to grassland, mainly because areas of burned forest were restored to grassland. Some forests $\left(3215.07 \mathrm{hm}^{2}\right)$ were converted to urban land because of forest road construction, and some forests $\left(2057.13 \mathrm{hm}^{2}\right)$ were converted to burned areas because of naturally occurring wildfires due to lightning strikes. The vast majority of grassland was converted to urban land $\left(17,870.31 \mathrm{hm}^{2}\right)$ and desert $\left(6067.89 \mathrm{hm}^{2}\right)$, accounting for $96.03 \%$ of the total conversion area of grassland. The primary reasons for this were urban expansion, road construction, and grassland desertification. Some farmland was converted to grassland $\left(20,098.71 \mathrm{hm}^{2}\right)$ and forest $\left(263.61 \mathrm{hm}^{2}\right)$, indicating that the Grain-for-Green Project was successful. Some farmland was converted to urban land $\left(7041.87 \mathrm{hm}^{2}\right)$ because of urban expansion and road construction. Some wetlands were converted to grassland $\left(10,834.11 \mathrm{hm}^{2}\right)$ and desert $\left(1913.31 \mathrm{hm}^{2}\right)$. Therefore, wetland protection must be strengthened. Some wetlands were converted to urban land $\left(3090.06 \mathrm{hm}^{2}\right)$, mainly due to road construction. Desert areas were converted to forests $\left(172.08 \mathrm{hm}^{2}\right)$, grassland $\left(5979.6 \mathrm{hm}^{2}\right)$, and wetland $\left(1285.92 \mathrm{hm}^{2}\right)$ because the local authorities adopted measures such as planting, aerial seeding, sand sealing conservation, and the reasonable utilization of water in accordance with local conditions. Most burned land was converted to forests $\left(6356.88 \mathrm{hm}^{2}\right)$, indicating that good progress has been made in vegetation restoration after wildfires. The order of the land cover types based on the proportion of change was farmland $>$ forest $>$ grassland $>$ wetland $>$ urban land $>$ desert $>$ burned land.

Table 2. Land cover transition matrix from 2000 to $2018\left(\mathrm{hm}^{2}\right)$.

\begin{tabular}{|c|c|c|c|c|c|c|c|c|}
\hline 2018 & Forest & Grassland & Farmland & Wetland & $\begin{array}{c}\text { Urban } \\
\text { Land }\end{array}$ & Desert & $\begin{array}{c}\text { Burned } \\
\text { Land }\end{array}$ & Total 2018 \\
\hline Forest & & $18,856.17$ & 0.00 & 1887.84 & 3215.07 & 46.26 & 2057.13 & $26,062.47$ \\
\hline Grassland & 279.63 & & 711.18 & 0.00 & $17,870.31$ & 6067.89 & 0.27 & $24,929.28$ \\
\hline Farmland & 263.61 & $20,098.71$ & & 993.69 & 7041.87 & 0.00 & 0.00 & $28,397.88$ \\
\hline Wetland & 558.90 & $10,834.11$ & 1514.61 & & 3090.06 & 1913.31 & 0.00 & $17,910.99$ \\
\hline Urban land & 4.59 & 22.50 & 0.63 & 4.95 & & 14.49 & 0.00 & 47.16 \\
\hline Desert & 172.08 & 5979.60 & 49.05 & 1285.92 & 837.00 & & 0.00 & 8323.65 \\
\hline Burned land & 6356.88 & 604.98 & 0.27 & 68.31 & 1.44 & 2348.91 & & 9380.79 \\
\hline Total 2000 & 7635.69 & $56,396.07$ & 2275.74 & 4240.71 & $32,055.75$ & $10,390.86$ & 2057.4 & $115,052.22$ \\
\hline
\end{tabular}

Table 3. Land cover transition matrix from 2000 to $2010\left(\mathrm{hm}^{2}\right)$.

\begin{tabular}{cccccccc}
\hline 2000 & 2010 & Forest & Grassland & Farmland & Wetland & $\begin{array}{c}\text { Urban } \\
\text { Land }\end{array}$ & $\begin{array}{c}\text { Burned } \\
\text { Land }\end{array}$ \\
\hline Forest & & $13,242.87$ & 0.09 & 1882.62 & 1194.75 & 57.69 & 4342.23 \\
Grassland & 157.77 & & 736.92 & 10.26 & 8569.35 & 7492.86 & 354.96 \\
Farmland & 265.86 & $20,171.43$ & & 1018.62 & 2816.82 & 0.00 & 0.00 \\
Wetland & 570.51 & $10,859.49$ & 1458.90 & & 778.32 & 1978.11 & 0.00 \\
Urban land & 15.30 & 2.70 & 0.00 & 0.09 & & 24.66 & 0.00 \\
Desert & 36.72 & 6362.01 & 50.40 & 1814.67 & 795.51 & 1.44 & 2349.00 \\
Burned land & 6324.39 & 118.08 & 0.27 & 68.40 & & 0.00 \\
\hline
\end{tabular}


Table 4. Land cover transition matrix from 2010 to $2018\left(\mathrm{hm}^{2}\right)$.

\begin{tabular}{cccccccc}
\hline 2000 & Forest & Grassland & Farmland & Wetland & $\begin{array}{c}\text { Urban } \\
\text { Land }\end{array}$ & $\begin{array}{c}\text { Desert } \\
\text { Burned } \\
\text { Land }\end{array}$ \\
\hline Forest & & 1338.03 & 0.00 & 21.60 & 1273.95 & 0.00 & 2043.36 \\
Grassland & 0.00 & & 325.89 & 0.00 & 2740.32 & 91.08 & 0.00 \\
Farmland & 0.00 & 0.00 & & 0.00 & 4035.42 & 0.00 & 0.00 \\
Wetland & 0.00 & 0.00 & 63.18 & & 928.17 & 0.00 & 0.00 \\
Urban land & 0.00 & 23.13 & 0.00 & 0.09 & & 0.00 & 0.00 \\
Desert & 277.20 & 381.42 & 0.00 & 54.72 & 909.54 & 0.00 \\
Burned land & 46.17 & 5156.28 & 0.00 & 0.00 & 0.00 & 0.00 & \\
\hline
\end{tabular}

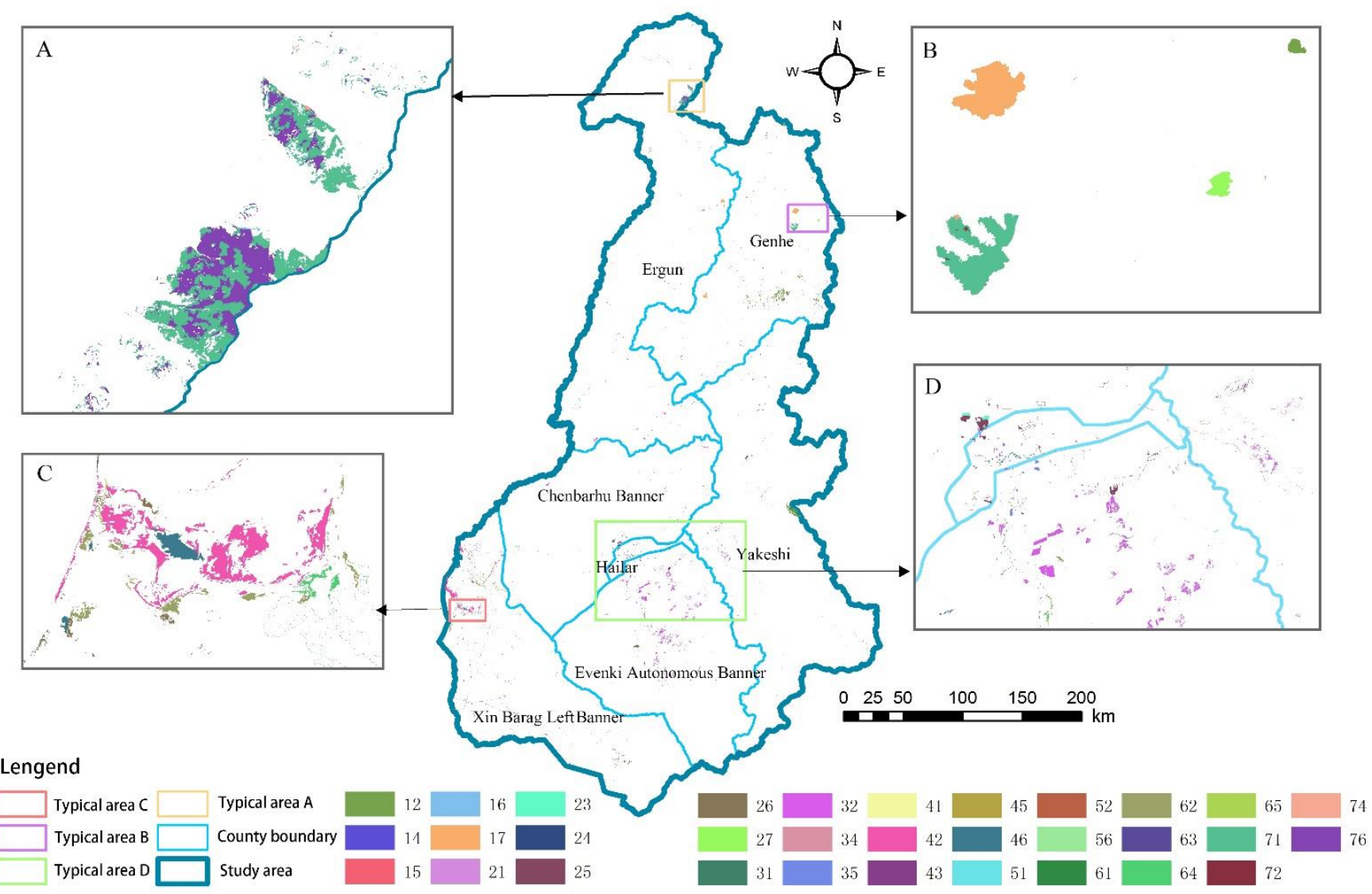

Figure 7. Land cover conversion map from 2000 to 2010: 1 represents forest; 2 represents grassland; 3 represents farmland; 4 represents wetland; 5 represents urban land; 6 represents desert; 7 represents burned land; 12 represents the change from forest to grassland; and 15 represents the change from forest to urban land.

The land cover types that were converted to grassland from 2000 to 2018 included forest $\left(18,856.17 \mathrm{hm}^{2}\right)$, farmland $\left(20,098.71 \mathrm{hm}^{2}\right)$, and wetland $\left(10,834.11 \mathrm{hm}^{2}\right)$. A total $23,548.95 \mathrm{hm}^{2}$ area of grassland changed to urban land. The increase in urban land was mainly due to the transitions of grassland, farmland, and wetland $\left(17,870.31 \mathrm{hm}^{2}\right.$, $7041.87 \mathrm{hm}^{2}$, and $3090.06 \mathrm{hm}^{2}$, respectively). The reasons for the large increase in construction land area (including roads) was population increase, rapid urbanization and increasing tourism in recent years. Overall, the areas of desert increased slightly from 2000 to 2018, indicating that desertification control achieved some positive results, but more work is required. The order of the land cover types that increased in area was grassland $>$ urban land $>$ desert $>$ forest $>$ wetland $>$ farmland $>$ burned land. 


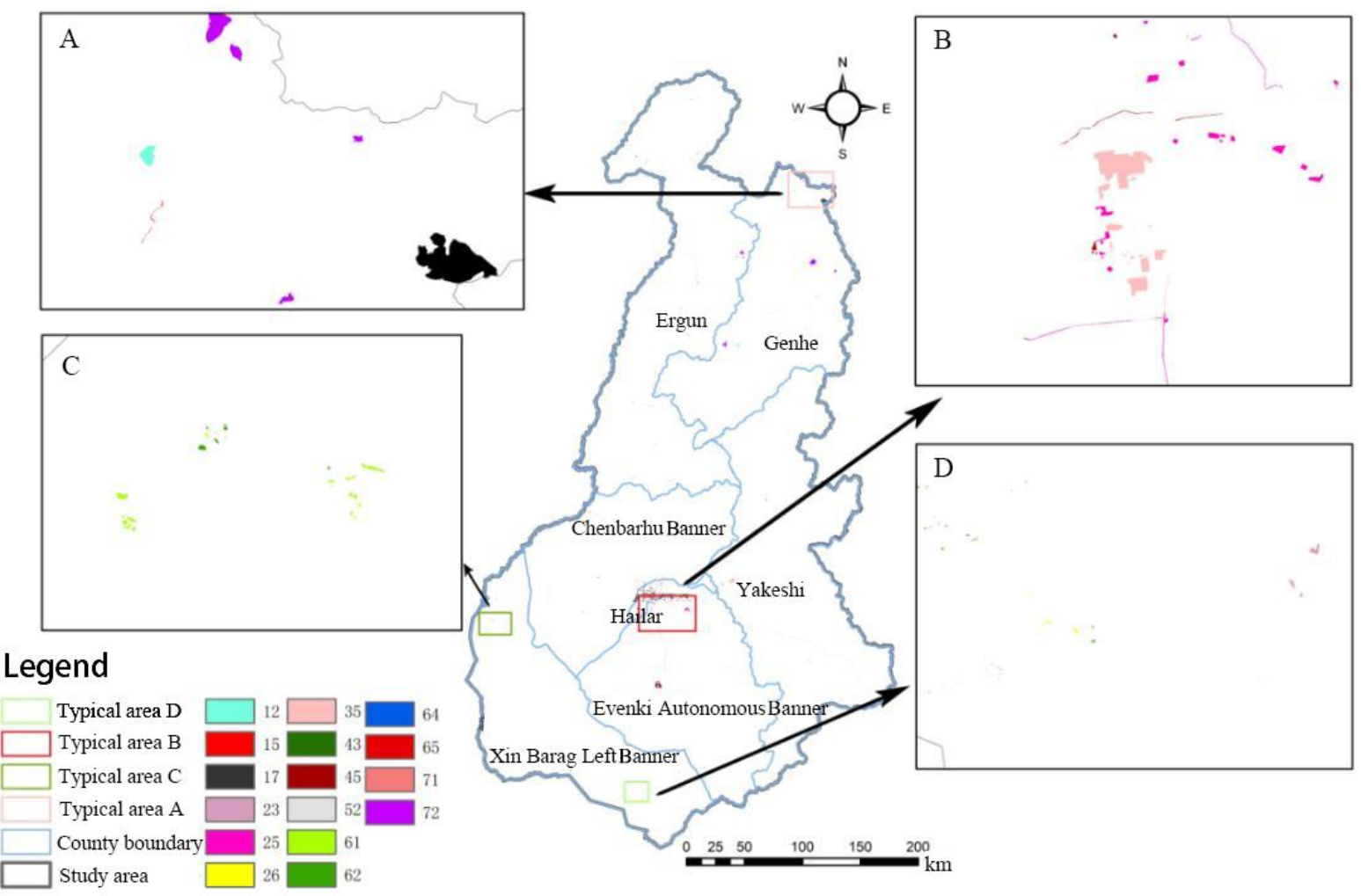

Figure 8. Land cover conversion map from 2010 to 2018: 1 represents forest; 2 represents grassland; 3 represents farmland; 4 represents wetland; 5 represents urban land; 6 represents desert; 7 represents burned land; 12 represents the change from forest to grassland; and 15 represents the change from forest to urban land.

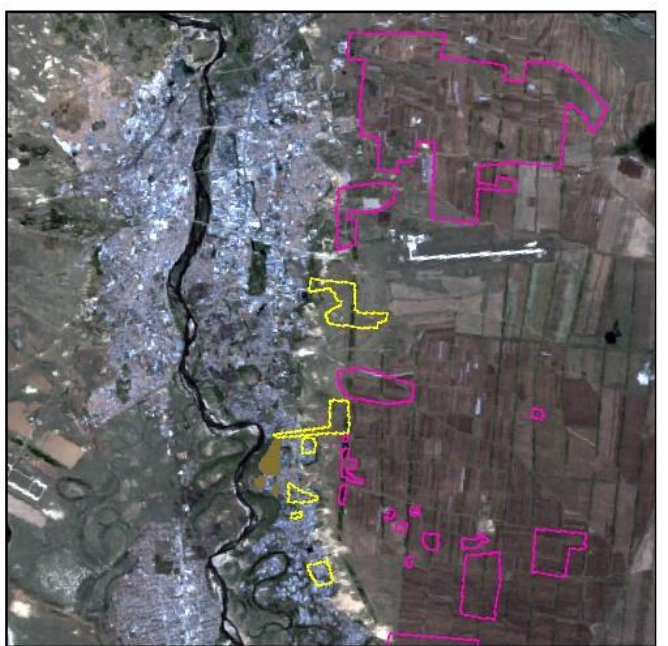

2000

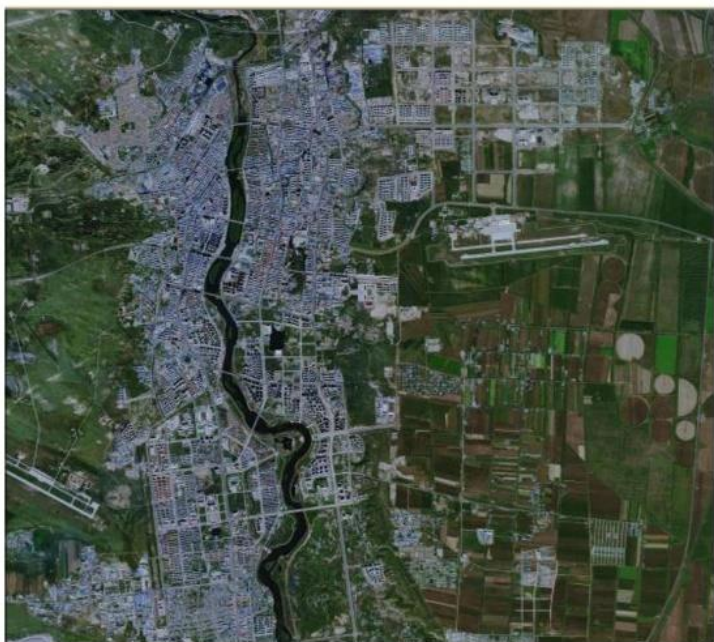

2018

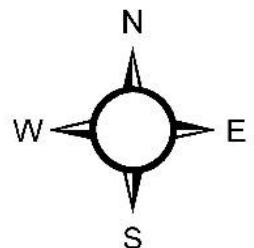

$\mathrm{S}$

\section{grassland to urban land}

\section{cropland to urban land}

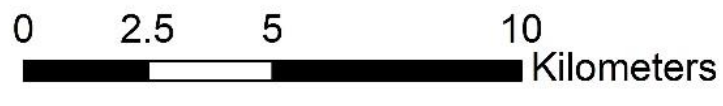

Figure 9. An exemplary area showing the comparison of the land cover change results and RGB ortho-mosaic images. 
A comparison of the land cover conversions between 2000-2010 and 2010-2018 (Tables 3 and 4) indicates that more land cover changes occurred in the early stage than in the later stage. More forest areas were converted in 2010-2018 than in 2000-2010. The main reason for this was that a comprehensive logging ban of natural forests was implemented in the Greater Khingan Mountains on 1 April 2015. Thus, the previous development and utilization of key state-owned forest areas changed to comprehensive protection. From 2010 to 2018, areas of desert changing into other land cover types were larger than areas changing into desert areas, indicating the successful control of desertification.

\subsection{FVC Change}

As shown in Table 5, 26.78\% of the study area exhibited a FVC change from 2000 to 2010. In general, most FVC changes from 2000 to 2010 consisted of decreases in the highcover areas and increases in the low-cover areas. This change was dominated by increases in saline-alkali land and desert areas, indicating significant grassland desertification from 2000 to 2010.

Table 5. FVC transition matrix from 2000 to $2010\left(\mathrm{hm}^{2}\right)$.

\begin{tabular}{|c|c|c|c|c|c|}
\hline 2010 & $\begin{array}{c}\text { Very Low } \\
\text { Cover }\end{array}$ & Low Cover & Medium Cover & High Cover & $\begin{array}{c}\text { Very High } \\
\text { Cover }\end{array}$ \\
\hline Very low cover & & $211,768.80$ & $12,550.00$ & 5843.75 & 7125.00 \\
\hline Low cover & $266,343.80$ & & $146,987.50$ & $28,206.25$ & $14,856.25$ \\
\hline Medium cover & $51,987.50$ & $439,612.50$ & & $120,962.50$ & $45,006.25$ \\
\hline High cover & $19,850.00$ & $110,731.30$ & $431,000.00$ & & $499,775.00$ \\
\hline Very higher cover & $56,225.00$ & $48,900.00$ & $240,943.80$ & $837,293.80$ & \\
\hline
\end{tabular}

As shown in Table 6, 30.8\% of the study area exhibited an FVC change from 2010 to 2018. In general, most FVC change in the study area consisted of increases in the highcover areas and decreases in the low cover areas from 2010 to 2018. This change was dominated by decreases in desert areas and increases in grassland areas, indicating that grassland desertification was minimized significantly after treatments, and the ecological environment had improved.

Table 6. FVC transition matrix from 2010 to $2018\left(\mathrm{hm}^{2}\right)$.

\begin{tabular}{cccccc}
\hline 2000 & $\begin{array}{c}\text { Very Low } \\
\text { Cover }\end{array}$ & Low Cover & Medium Cover & High Cover & $\begin{array}{c}\text { Very High } \\
\text { Cover }\end{array}$ \\
\hline Very low cover & & $211,768.80$ & $12,550.00$ & 5843.75 & 7125.00 \\
$\quad$ Low cover & $266,343.80$ & & $146,987.50$ & $28,206.25$ & $14,856.25$ \\
Medium cover & $51,987.50$ & $439,612.50$ & & $120,962.50$ & $45,006.25$ \\
$\quad$ High cover & $19,850.00$ & $110,731.30$ & $431,000.00$ & & $499,775.00$ \\
Very higher cover & $56,225.00$ & $48,900.00$ & $240,943.80$ & $837,293.80$ & \\
\hline
\end{tabular}

Figure 10 shows the FVC changes occurring from 2000 to 2010 and from 2010 to 2018. Areas with absolute values of FVC change greater than 0.4 were defined as areas of significant change. Those with values of 0.2 to 0.4 were categorized as areas of relatively slight change, and those with values less than 0.2 were considered areas of no change.

Overall, areas with low and very low vegetation cover increased, and areas with high and very high vegetation cover decreased from 2000 to 2010. The FVC in the study area showed a downward trend, and the areas of decrease were concentrated around the Hailar District and the forest-steppe ecotone in southern Ergun. The results showed that the forest-steppe ecotone exhibited serious ecological degradation from 2000 to 2010. From 2010 to 2018, the low- and very-low-cover areas decreased significantly, whereas the highand very-high-cover areas increased. The FVC showed an upward trend, and the areas of increase were concentrated in the forest-steppe ecotone, saline-alkali land, and desert 
2000-2010
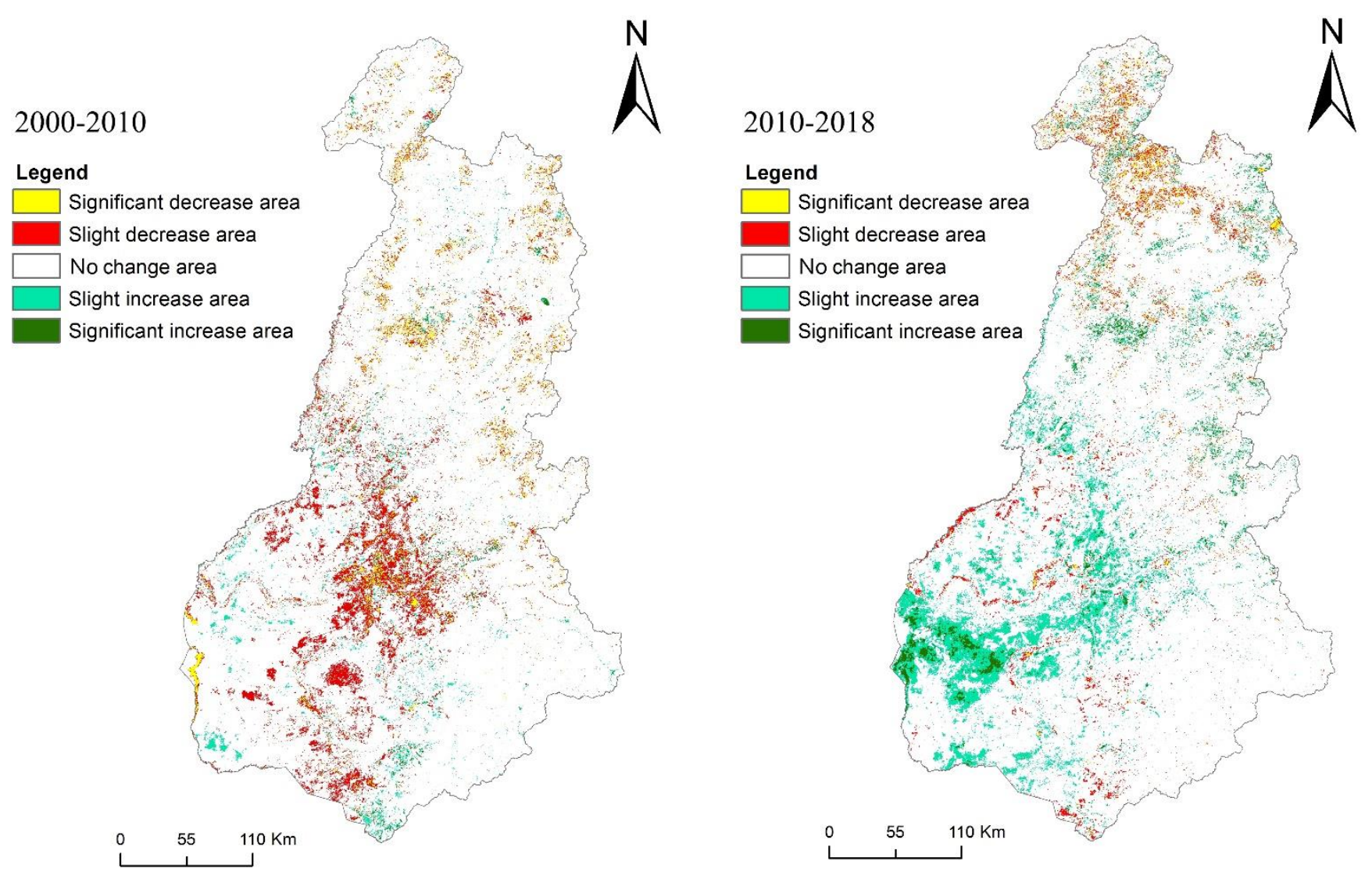

in Xin Barag Left Banner. The results showed that local control measures were relatively successful, and the ecological policies showed a positive effect from 2010 to 2018 .

Figure 10. FVC change in the forest-steppe ecotone from 2000 to 2010 (left) and from 2010 to 2018 (right).

\subsection{NPP Change}

As shown in Table 7, the total, mean, and maximum annual NPP of the forest-steppe ecotone in the Greater Khingan Mountains increased from 2000 to 2018, but the rate of increase decreased. The total NPP increased by $26.3 \%$ from 2000 to 2010 and by $10.8 \%$ from 2010 to 2018.

Table 7. NPP derived from the CASA model from 2000 to 2018.

\begin{tabular}{cccc}
\hline Year & Total $\mathbf{( g C )}$ & Mean $\mathbf{( g C \cdot \mathbf { m } ^ { - 2 } )}$ & Maximum $_{\left.\mathbf{~} \mathbf{g C} \cdot \mathbf{m}^{-\mathbf{2}}\right)}$ \\
\hline 2000 & $215,545,376$ & 401.58 & 689.37 \\
2010 & $285,986,592$ & 532.85 & 835.06 \\
2018 & $320,556,992$ & 597.44 & 1002.11 \\
\hline
\end{tabular}

Figure 11 shows the spatiotemporal changes in NPP between 2000 and 2010 (left) and between 2010 and 2018 (right). Areas where the difference in NPP between the two dates exceeded the mean were regarded as areas of significant increase. Areas where the difference in NPP was less than the mean and negative were defined as areas of slight decrease. If the values were positive, the areas were defined as areas of normal increase. 


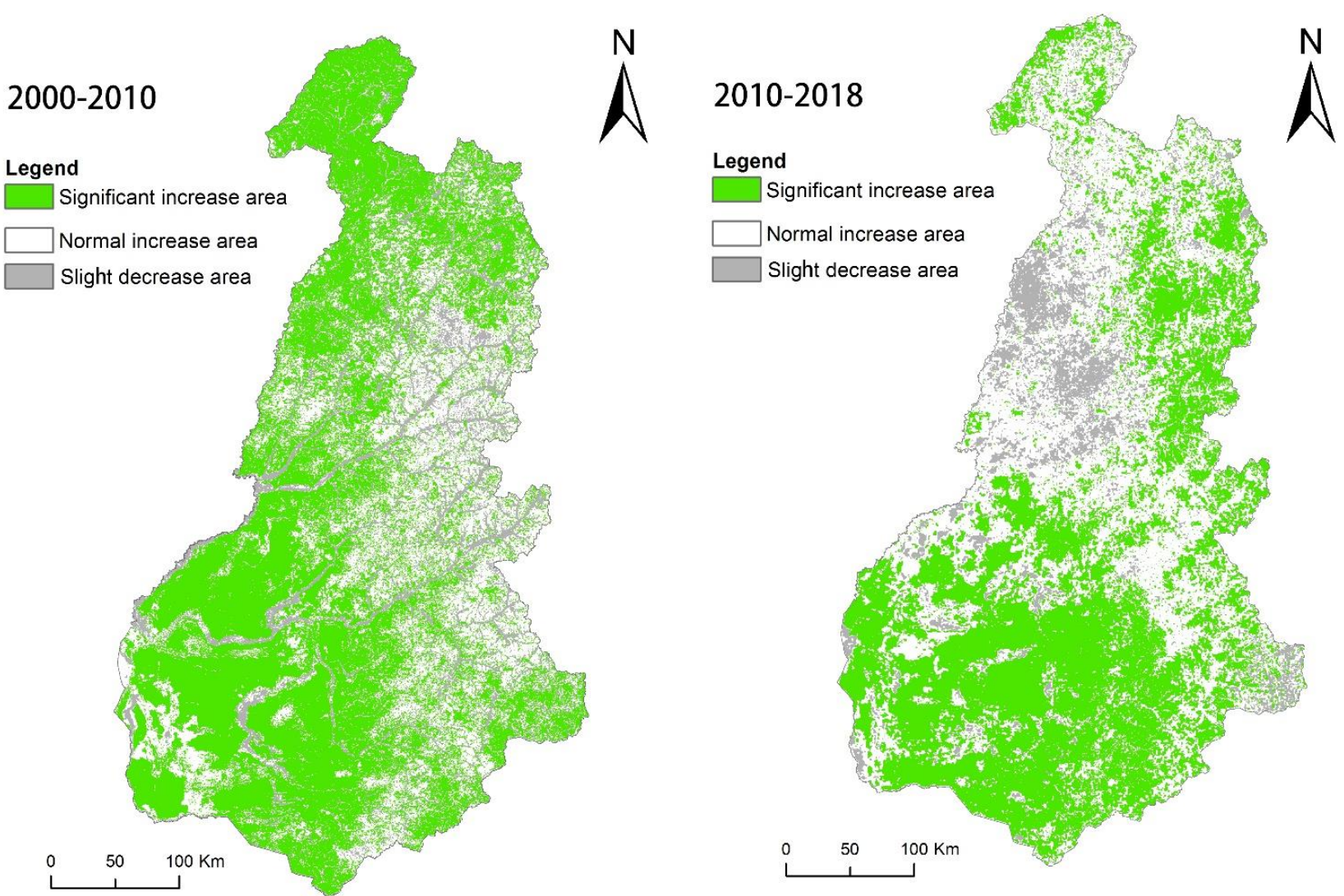

Figure 11. NPP change in the forest-steppe ecotone from 2000 to 2010 (left) and from 2010 to 2018 (right).

From 2000 to 2010, NPP increased substantially in the grassland areas. NPP in the forest areas increased substantially only in Ergun, northern Genhe, and southern Yakeshi, and NPP near the wetlands decreased slightly. From 2010 to 2018, NPP increased significantly in the southern grassland area. NPP in the forest areas decreased slightly south of Yakeshi and Ergun.

\subsection{Spatiotemporal Change in Land Cover and Ecological Quality}

By comparing the spatial distribution of land cover changes with FVC and NPP changes, the impact of land cover changes on ecological quality can be found. Hailar District, as the political, economic and cultural center of Hulunbuir City, due to the urban population increase and development needs, experienced large urban expansion from 2000 to 2018, resulting in severe land cover changes. The changes were even more dramatic from 2000 to 2010, as shown in Figure 12. The increase in urban land and desert leads to significant decrease in FVC, also leads a lag effect on NPP. With the gradual implementation of various ecological protection policies from 2010 to 2018, the Hailar District exhibited a large area of FVC increase, whereas NPP slightly decreased where the urban land increased. This shows that the impact of urban expansion on NPP is greater than that of ecological restoration. Otherwise, the ecological quality was directly deteriorated in the increased burned areas and desert, except for the burned land turned into desert, as shown in Figure 13. 


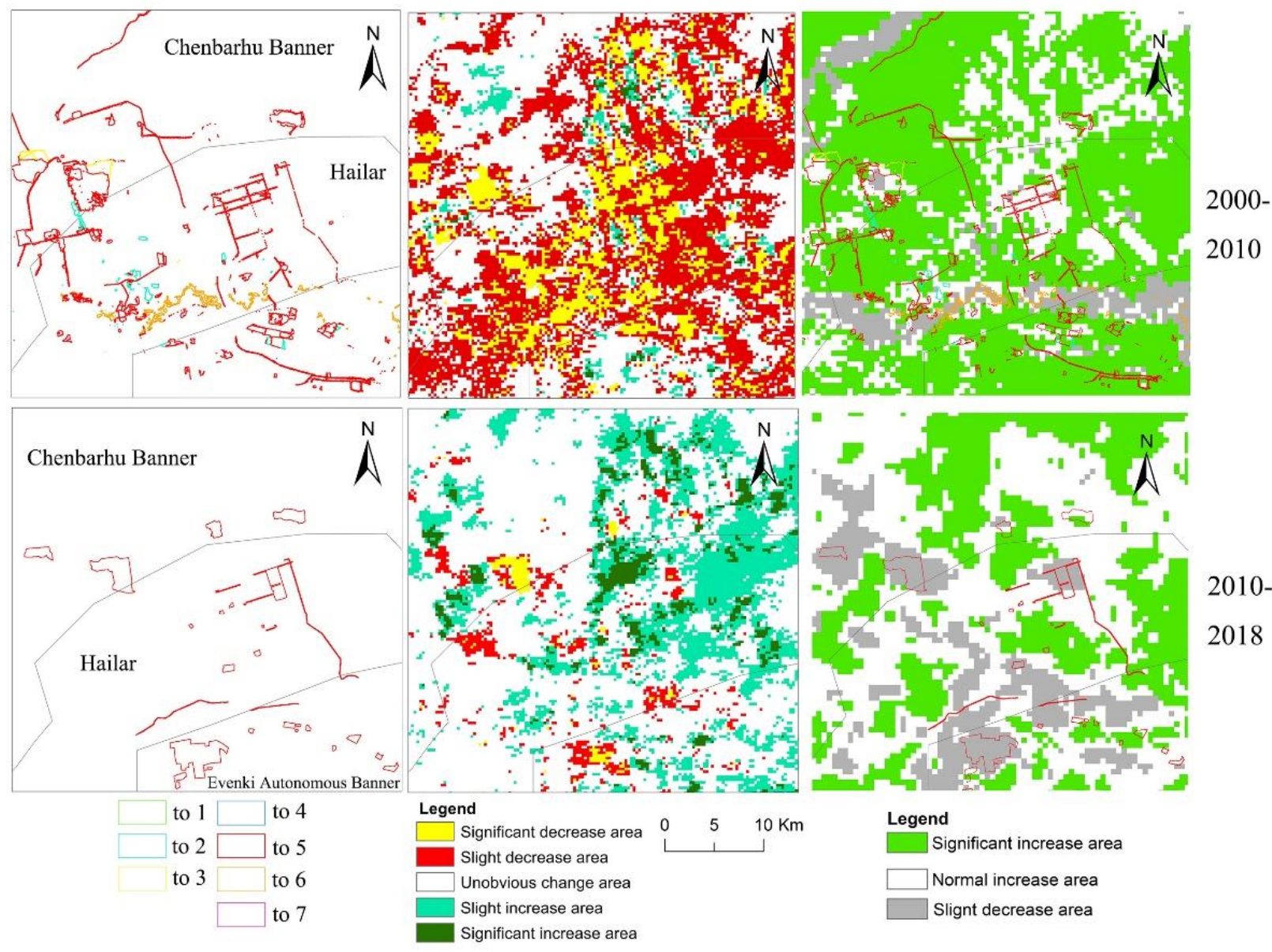

Figure 12. Spatiotemporal change in land cover and ecological quality in Hailar District: 1 represents forest; 2 represents grassland; 3 represents farmland; 4 represents wetland; 5 represents urban land; 6 represents desert; 7 represents burned land; "to 1 " represents the change from other land cover types to forest; and "to 2 " represents the change from other land cover types to grassland. 

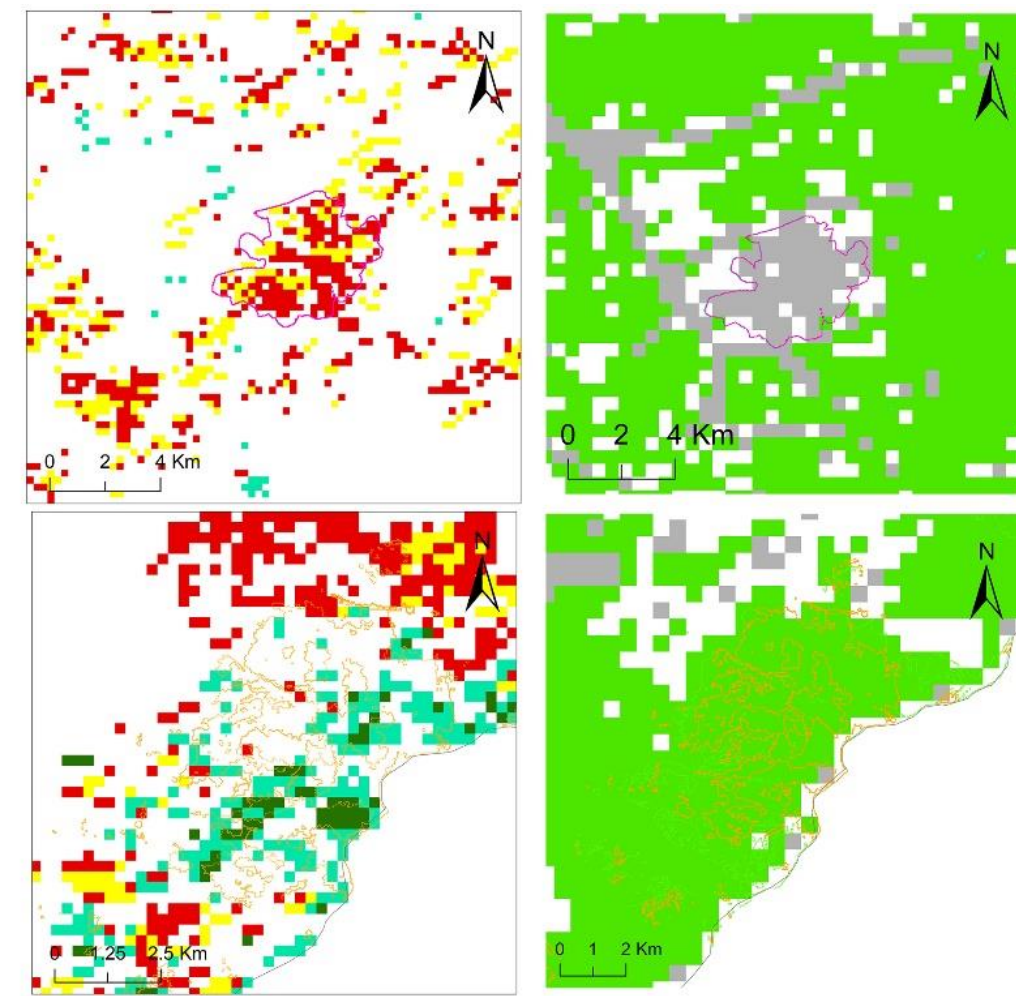

Legend

Significant increase area

$\square$ Normal increase area

Slignt decrease area

\section{0-2010}

\section{Legend}

$\square$ Significant decrease area

Slight decrease area

Unobvious change area

Slight increase area

Significant increase area

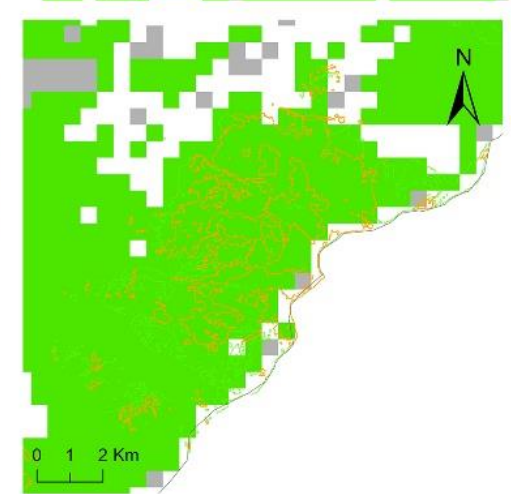

Legend

Significant increase area

Normal increase area

Slignt decrease area
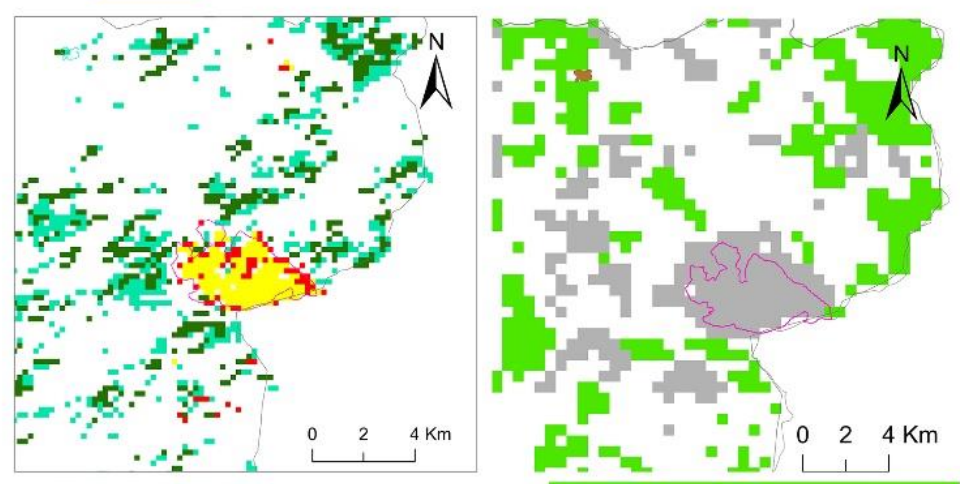

2010-2018

$\square$ to burned land
to desert

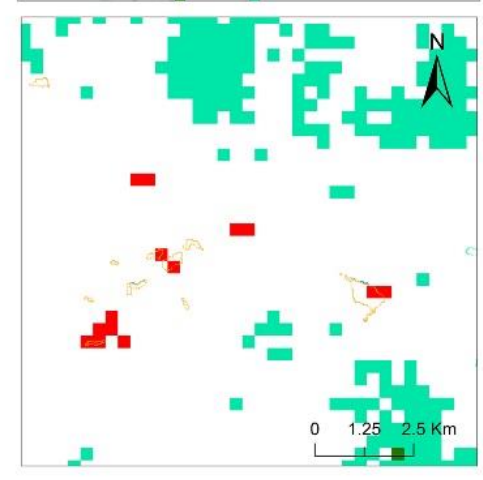

FVC

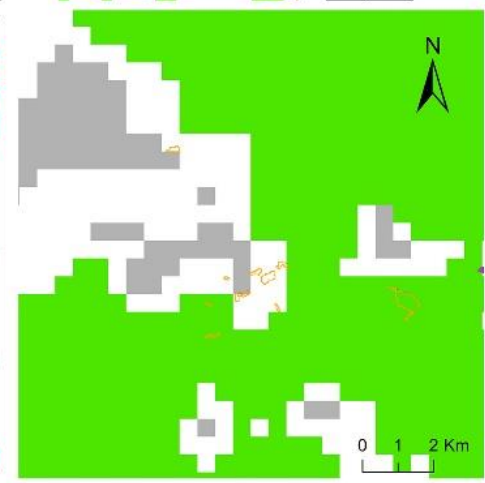

NPP

Figure 13. The FVC and NPP changes of the increase areas of burned land and desert.

\section{Discussion}

\subsection{Management and Policy Implications of Land Cover Change}

Land is required for producing products, and LUCC affects regional ecological stability. However, land cover transformation often has positive or negative impacts on the ecosystem and ecological environment directly or indirectly. When the contribution rate of the land cover changes and improves the ecological environment rather than degrade 
the ecological environment, the ecological quality improves; otherwise, it declines [54]. In this work, land cover maps were created, and spatiotemporal changes in the NPP and FVC in a 20-year period were analyzed to determine the ecological quality changes in the forest-steppe ecozone of the Greater Khingan Mountains, northeast China. The results, specifically the substantial changes in grassland, farmland, urban construction land, and desert areas, provide data for the targeted formulation of management strategies and political measures, which are detailed subsequently.

4.1.1. Strict Enforcement of Forest Fire Prevention and Suppression Regulations and Forest Restoration Schemes in Burned Lands

The main reasons for the decrease in forest cover in the study area are forest fires and farmland encroachment. The land cover transition matrix shows that $2057.13 \mathrm{hm}^{2}$ of forestland changed to burned land, and $6356.88 \mathrm{hm}^{2}$ of burned land was restored to forestland from 2000 to 2018 (Table 2). During this period, forest fires mainly occurred in the woodlands of Ergun and Genhe, which is the northern part of the forest-steppe ecotone in the Greater Khingan Mountains. The annual NPP of the study area increased substantially by 105,011,616 gC from 2000 to 2018 (Table 5). This finding shows that the vegetation productivity and the overall quality of the ecosystems improved. Rihan et al. (2019) used a random forest (RF) model to analyze the contribution rates of various influencing factors and the probability of fire occurring on the Mongolian Plateau [55]. The results indicated that the areas with the highest wildfire probabilities were concentrated in the northern, eastern, and southern parts of the Mongolian Plateau. Due to favorable weather and vegetation conditions, the northern Greater Khingan Mountains and the eastern region have the highest probability of wildfire [56]. The occurrence and spread of wildfires are less likely in desert areas due to a low fuel load; thus, the wildfire probability in these areas is the lowest [57]. In this study, we propose several suggestions for the restoration of burned areas in the forest-steppe ecotone of the Greater Khingan Mountains. Natural succession is preferable in burned areas with poor site conditions, low soil temperatures, thin soil layers, difficult access, and an inability to perform adequate management. Low-intensity fires can promote natural regeneration. In moderately to severely burned areas with a large number of remaining trees, natural regeneration is a good choice using seed trees or planting seedlings. Burned trees should be removed to prevent plant diseases and minimize insect pests and rodents. In severely burned areas with a majority of dead vegetation, replanting and aerial seeding are the best choices according to the characteristics of the original forest to accelerate forest succession and achieve ecological restoration.

\subsubsection{Increasing the Amount of Cropland Conversion to Grassland}

According to the land cover transition matrix, 20,098.71 hm² of farmland was converted to grassland, but only $711.18 \mathrm{hm}^{2}$ of grassland was converted into farmland in the forest-steppe ecotone of the Greater Khingan Mountains in the past 18 years (Table 2). Most areas of farmland were converted to grassland from 2000 to 2010 (Table 3), whereas only a small amount of farmland was converted from 2010 to 2018 (Table 4). This finding shows that the rate of expansion of farmland has slowed in recent years, and the policy of returning farmland to grassland has achieved good results. These results are consistent with previous research. For example, Fang and Fan (2020) found that the main source of grassland increase was cultivated land in the Hulunbuir grassland, and large areas of wetland were converted into grassland in the Hailar District [58].

In addition, the FVC of grassland increased significantly, which was consistent with the land cover classification results. The total grassland area increased continuously by $37,176.39 \mathrm{hm}^{2}$ from 2000 to 2018 (Table 2), showing an increasing trend. However, some deserts expanded in the grassland-desert ecotone, which should be further investigated. For example, $7492.86 \mathrm{hm}^{2}$ of grassland degraded into the grassland-desert ecotone in southeastern Xin Barag Left Banner because of grazing and other factors from 2000 to 2010 (Table 3). Wang and Yang (2012) used MODIS data to develop a model for assessing 
the livestock carrying capacity and overgrazing, and found 10,730.4 $\times 10^{3}$ sheep units in Hulunbuir [57]. Overgrazing is a problem that must be addressed. Inner Mongolia implemented the "Forage and Livestock Contracting" policy in 1983 to assign forage and livestock to each herder [59]. The policy resulted in an increased livestock population and intensified desertification. Several desertification control measures, such as banning grazing and planting sand-stabilizing plants on grasslands, have been successively implemented since 2000 [59]. The government formulated policies for "Further Strengthening the Rules for the Implementation of Regulations on the Supervision and Administration of Grassland in the Inner Mongolia Autonomous Region" in 2005 to strengthen grassland supervision and management work $[60,61]$. Therefore, we should continue to promote policies of returning grazing land to grassland in the forest-steppe ecotone of the Greater Khingan Mountains, accelerate the transformation of grassland animal husbandry production, and reduce damage to grasslands. Fortunately, our current study is highly applicable to evaluate the effectiveness of the policies and measures and to inform land managers or decisionmakers in these areas about abrupt land changes.

\subsubsection{Strengthening Desertification Control}

The land cover transition matrix showed that desert areas increased by $2843.01 \mathrm{hm}^{2}$ from 2000 to 2010 (Table 3). The main reasons for this include overgrazing, improper reclamation, improper management, and unclear management authority. However, in 2010-2018, only $91.08 \mathrm{hm}^{2}$ of grassland was converted into desert area (Table 4). In some areas of Xin Barag Left Banner, $381.42 \mathrm{hm}^{2}$ of desert areas was converted into grassland, and $277.20 \mathrm{hm}^{2}$ of desert areas was converted into woodland (Table 4), substantially improving water conservation and the wind- and sand-stabilization capacity of the ecosystem. This change was closely related to improvements in desertification management by the government. For example, in 2013, the government of Xin Barag Left Banner established a national project of protecting land to reduce desertification. As a result, grassland loss and degradation in the forest-steppe ecotone were mitigated. Thus, we propose the following suggestions. In areas of grassland degradation, desertification, and salinization, the local government should take timely control measures to ensure sustainable development, such as enclosures, afforestation, windbreaks, and sand-stabilization. In areas of severe desertification, the government should optimize the industrial structure of the region and encourage industrial transformation to reduce damage to grassland resources and to prevent desertification.

\subsubsection{Promoting a Modern Transportation System}

Our results showed that approximately $1194.75 \mathrm{hm}^{2}$ and $1273.95 \mathrm{hm}^{2}$ of forestland were used for forest road construction in 2000-2010 (Table 3) and 2010-2018 (Table 4), respectively. Most of these changes occurred in Ergun and Yakeshi, and some occurred in the Genhe region. Forest road construction mainly focused on improving the structure and quality of the original trunk road surface and building a new trunk line for forest fire monitoring, prevention, and tourism. In addition, many new roads were constructed in grassland areas. Approximately $17,870.31 \mathrm{hm}^{2}$ of grassland was used for urban expansion and road construction from 2000 to 2018 (Table 2). Wang et al. (2013) analyzed land use changes from 2000 to 2010 in the Hulunbuir grassland and found that urban land, mining land, and residential land increased by more than $400 \mathrm{~km}^{2}$. Although road construction can stimulate economic growth, it can adversely affect the ecological environment, reduce the connectivity between grassland patches, and limit the activities of grassland animals. Therefore, we should conduct scientific surveys and evaluate the ecosystem functions in areas of planned roads to minimize the negative impacts of road construction on grassland and forest areas. 


\subsection{NPP and FVC Change}

The annual average NPP was higher in the forest areas of the Greater Khingan Mountains and lower in the grassland area (Figure 6). Our NPP results in the Hulunbuir area are consistent with other NPP studies in Inner Mongolia $[62,63]$. For example, it was observed that NPP in Inner Mongolia grasslands decreased from the northeast to the southwest [64]. Zhao et al. (2019) analyzed NPP and its spatiotemporal variations in Inner Mongolia using linear trend analysis and found that NPP increased over time [65]. The interannual variation trend and annual mean NPP in this study were consistent with the results of these studies (Figure 6). Chen et al. (2012) used an improved light energy utilization model and found that the NPP per unit area in the eastern forest-steppe ecotone of the Greater Khingan Mountains showed a weak downward trend [66]. Land cover has a significant impact on NPP, especially in the forest-steppe ecotone and Inner Mongolia. It was found that the NPP of vegetation decreased in the forest-steppe ecotone [67]. Forest fires occurred in the southern Ergun forest areas in 2010-2018. In this study, we obtained NPP using the CASA model and found that the annual NPP decreased slightly in the forest-steppe ecotone, i.e., in Yakeshi and southern Ergun (Figure 6).

The FVC in our study area decreased from the northeast to southwest (Figure 7). Other studies also found that the FVC was higher in the forest areas of the Greater Khingan Mountains and lower in the grasslands [68,69]. We observed a decreasing trend in FVC from 2000 to 2010 and a slow upward trend from 2010 to 2018 (Figure 7). Particularly, from 2000 to 2018, the vegetation conditions in some parts of the Hulunbuir grassland improved, especially in the western part of Xin Barag Right Banner (Figure 7). Peng et al. (2017) analyzed FVC in the Hulunbuir steppe (2000-2014) and found an overall decrease in vegetation cover in the entire study area in the first 10 years and a slow increase in the last 5 years [70]. Li et al. (2014) observed a decreasing trend with fluctuations in grassland FVC (2000-2013) in the forest-steppe ecotone of the Greater Khingan Mountains [71]. These findings were in agreements with our results, although the periods were not identical. Precipitation is the key factor affecting the interannual variation in grassland vegetation cover, and regional socioeconomic activities also affect grassland degradation in Hulunbuir. In the early 1950s, only 29,100 people were directly engaged in grazing-related activities in grasslands. By the end of 2016, this number had increased to 71,000. Due to a population increase in pastoral areas, herdsmen mainly rely on increasing livestock production to maintain their livelihood, leading to extensive overgrazing of grasslands in pastoral areas and reducing the FVC and NPP of grasslands.

\subsection{Limitations and Challenges}

Compared with land cover change research, this study has the following limitations. Seasonal snowpack substantially influences the regional water stress gradient and interannual variation in NPP by affecting the soil moisture in the next growing season [72]. Due to data unavailability, we did not examine the impacts of mining and urban sprawl on the ecological environment $[73,74]$. We also did not differentiate land type conversions on different slopes and did not consider the land type patterns in different terrains [75]. For example, climatic changes can cause major shifts in dune activity [76]. Liu et al. (2014) analyzed the conversion between paddy fields and dryland in cultivated land [77]. In this study, the classification of land cover in the river watersheds was relatively coarse, requiring improvements in a follow-up study. In addition, the spatial heterogeneity of the ecological environment in the study area requires more in-depth analysis to provide more accurate suggestions for ecological environmental protection. This whole study was time-consuming and labor-intensive; therefore, we are now integrating the workflow and GEE platform to save resources and improve analytical efficiency to be more global and widespread. 


\section{Conclusions}

In this study, we performed a comprehensive, spatially explicit evaluation of the evolution in land cover and ecological quality by integrating deep learning and multisource remote sensing based on modeling algorithms.

We found that from 2000 to 2018, forest areas decreased and grassland increased in the study area. The main driving force was forest fires and the subsequent recovery to grasslands. The increase in grassland was mainly attributed to the restoration of burned land and the degradation of wetlands. Grassland degradation remains a significant problem due to its conversion to urban land. Saline-alkali land and desert areas first increased and then decreased; thus, grassland desertification improved. The farmland area decreased, indicating good progress in returning farmland to forests and grasslands.

Additionally, the annual NPP in the study area showed an overall upward trend and increased continuously from the southwest to northeast, with a substantial increase in the northeastern forest areas and western grasslands. However, the rate of increase in NPP in the wetland areas and the southern area of Ergun (forest-steppe ecotone) was slow or negative. FVC decreased in the forest-steppe ecotone from 2000 to 2010 and increased substantially from 2010 to 2018, especially in deserts and grasslands. Most changes in the FVC type occurred between adjacent cover classes and primarily from low vegetation cover to high vegetation cover areas. The main reasons for the improvements in the ecological environment were the conversion of farmland to forest and grassland, the protection of natural forests and desertification control policies.

Thus, from these results, we suggest that the restoration of burned areas, the promotion of modern eco-friendly transportation systems, and the strengthening of desertification control should be further promoted. The findings from our study can provide potential insights for land use planning and the development of ecological protection actions in this particular ecosystem, and the managerial or political implications behind the current work are essential for the sustainable development of ecological interests.

Author Contributions: Conceptualization, M.L. (Mingshi Li); methodology, F.S., J.Q., Y.Z., H.S. and M.L. (Mingshi Li); software, F.S. and J.Q.; validation, F.S., M.L. (Mingxing Liu), J.F. and J.C.; formal analysis, F.S., Y.Z. and H.S.; investigation, F.S., M.L. (Mingxing Liu), J.Q., Y.Z., H.S., X.M., X.L., J.F., J.C. and M.L. (Mingshi Li); resources, Y.L., W.X. and Z.W.; data curation, F.S., M.L. (Mingxing Liu) and Y.Z.; writing-original draft preparation, F.S. and M.L. (Mingxing Liu); writing-review and editing, F.S. and M.L. (Mingshi Li); visualization, F.S., M.L. (Mingxing Liu) and X.M.; supervision, Y.Z., Y.L., W.X., Z.W. and M.L. (Mingshi Li); project administration, Y.Z. and M.L. (Mingshi Li); funding acquisition, Y.L., W.X., Z.W. and M.L. (Mingshi Li) All authors have read and agreed to the published version of the manuscript.

Funding: This research was funded by the National Natural Science Foundation of China [grant No. 31971577], the Biodiversity Investigation, Observation and Assessment Program sponsored by the Ministry of Ecology and Environment of China (2019-2023), and the Priority Academic Program Development (PAPD) of Jiangsu Higher Education Institutions.

Institutional Review Board Statement: Not applicable.

Informed Consent Statement: Not applicable.

Data Availability Statement: Not applicable.

Conflicts of Interest: The authors declare no conflict of interest. The funders had no role in the design of the study; in the collection, analyses, or interpretation of data; in the writing of the manuscript; or in the decision to publish the results. 


\section{Appendix A}

Table A1. Error matrix of land cover classification in 2000.

\begin{tabular}{|c|c|c|c|c|c|c|c|c|c|}
\hline $\begin{array}{l}\text { Reference Map } \\
\text { Classification Map }\end{array}$ & Forest & Grassland & Farmland & Wetland & $\begin{array}{l}\text { Urban } \\
\text { Land }\end{array}$ & Desert & $\begin{array}{c}\text { Burned } \\
\text { Land }\end{array}$ & Total & $\begin{array}{l}\text { Producer } \\
\text { Accuracy }\end{array}$ \\
\hline Forest & 236 & 5 & 0 & 3 & 1 & 0 & 0 & 245 & $96.33 \%$ \\
\hline Grassland & 6 & 227 & 5 & 10 & 5 & 2 & 1 & 256 & $88.67 \%$ \\
\hline Farmland & 1 & 6 & 92 & 1 & 0 & 0 & 0 & 100 & $92.00 \%$ \\
\hline Wetland & 2 & 3 & 1 & 182 & 3 & 6 & 0 & 197 & $92.39 \%$ \\
\hline Urban land & 0 & 2 & 0 & 0 & 89 & 0 & 0 & 91 & $97.80 \%$ \\
\hline Desert & 0 & 2 & 0 & 0 & 0 & 90 & 0 & 92 & $97.83 \%$ \\
\hline Burned land & 0 & 0 & 0 & 0 & 0 & 0 & 19 & 19 & $100 \%$ \\
\hline Total & 245 & 245 & 98 & 196 & 98 & 98 & 20 & 1000 & \\
\hline User accuracy & $96.33 \%$ & $92.65 \%$ & $93.88 \%$ & $92.86 \%$ & $90.82 \%$ & $91.84 \%$ & $95.00 \%$ & & \\
\hline \multicolumn{4}{|c|}{ Overall accuracy } & $93.50 \%$ & \multicolumn{2}{|c|}{ Kappa coefficient } & 0.9198 & & \\
\hline
\end{tabular}

Table A2. Error matrix of land cover classification in 2010.

\begin{tabular}{|c|c|c|c|c|c|c|c|c|c|}
\hline $\begin{array}{l}\text { Reference Map } \\
\text { Classification Map }\end{array}$ & Forest & Grassland & Farmland & Wetland & $\begin{array}{l}\text { Urban } \\
\text { Land }\end{array}$ & Desert & $\begin{array}{c}\text { Burned } \\
\text { Land }\end{array}$ & Total & $\begin{array}{l}\text { Producer } \\
\text { Accuracy }\end{array}$ \\
\hline Forest & 234 & 4 & 3 & 3 & 2 & 0 & 1 & 247 & $94.74 \%$ \\
\hline Grassland & 5 & 229 & 5 & 7 & 6 & 5 & 0 & 257 & $89.10 \%$ \\
\hline Farmland & 1 & 4 & 87 & 1 & 0 & 0 & 0 & 93 & $93.55 \%$ \\
\hline Wetland & 5 & 2 & 3 & 184 & 2 & 0 & 0 & 196 & $93.88 \%$ \\
\hline Urban land & 0 & 1 & 0 & 0 & 88 & 0 & 0 & 89 & $98.88 \%$ \\
\hline Desert & 0 & 5 & 0 & 1 & 0 & 93 & 0 & 99 & $93.94 \%$ \\
\hline Burned land & 0 & 0 & 0 & 0 & 0 & 0 & 19 & 19 & $100 \%$ \\
\hline Total & 245 & 245 & 98 & 196 & 98 & 98 & 20 & 1000 & \\
\hline \multirow{2}{*}{$\begin{array}{c}\text { Iotal } \\
\text { User accuracy }\end{array}$} & $95.51 \%$ & $93.47 \%$ & $88.78 \%$ & $93.88 \%$ & $89.80 \%$ & $94.90 \%$ & $95.00 \%$ & & \\
\hline & & \multicolumn{2}{|c|}{ Overall accuracy } & $93.40 \%$ & Kappa & ficient & 0.9156 & & \\
\hline
\end{tabular}

Table A3. Error matrix of land cover classification in 2018.

\begin{tabular}{|c|c|c|c|c|c|c|c|c|c|c|}
\hline \multicolumn{2}{|c|}{$\begin{array}{l}\text { Reference Map } \\
\text { Classification Map }\end{array}$} & \multirow{2}{*}{$\begin{array}{c}\text { Forest } \\
6\end{array}$} & \multirow{2}{*}{$\begin{array}{c}\text { Grassland } \\
3\end{array}$} & \multirow{2}{*}{$\begin{array}{c}\text { Farmland } \\
4\end{array}$} & \multirow{2}{*}{$\begin{array}{c}\text { Wetland } \\
0\end{array}$} & \multirow{2}{*}{$\begin{array}{c}\begin{array}{c}\text { Urban } \\
\text { Land }\end{array} \\
1\end{array}$} & \multirow{2}{*}{$\begin{array}{c}\text { Desert } \\
0\end{array}$} & \multirow{2}{*}{$\begin{array}{c}\begin{array}{c}\text { Burned } \\
\text { Land }\end{array} \\
275\end{array}$} & \multirow{2}{*}{$\begin{array}{c}\text { Total } \\
94.91 \%\end{array}$} & $\begin{array}{l}\text { Producer } \\
\text { Accuracy }\end{array}$ \\
\hline Forest & 261 & & & & & & & & & \\
\hline Grassland & 6 & 201 & 6 & 6 & 1 & 4 & 0 & 224 & $89.73 \%$ & \\
\hline Farmland & 4 & 3 & 106 & 1 & 1 & 1 & 0 & 116 & $91.38 \%$ & \\
\hline Wetland & 4 & 3 & 3 & 161 & 1 & 6 & 0 & 178 & $90.45 \%$ & \\
\hline $\begin{array}{l}\text { Urban } \\
\text { land }\end{array}$ & 1 & 2 & 0 & 0 & 71 & 0 & 2 & 76 & $93.42 \%$ & \\
\hline Desert & 3 & 5 & 1 & 8 & 2 & 87 & 1 & 107 & $81.31 \%$ & \\
\hline Burned & 1 & 0 & 1 & 0 & 4 & 1 & 17 & 24 & $70.83 \%$ & \\
\hline Total & 280 & 220 & 120 & 180 & 80 & 100 & 20 & 1000 & & \\
\hline $\begin{array}{l}\text { User } \\
\text { accu- }\end{array}$ & $93.21 \%$ & $91.36 \%$ & $88.33 \%$ & $89.44 \%$ & $88.75 \%$ & $87.00 \%$ & $85.00 \%$ & & & \\
\hline racy & & & \multicolumn{2}{|c|}{ Overall accuracy } & $90.40 \%$ & \multicolumn{2}{|c|}{ Kappa coefficient } & 0.8816 & & \\
\hline
\end{tabular}






Figure A1. Comparison of NPP obtained from the CASA model and MODIS products in 2000.

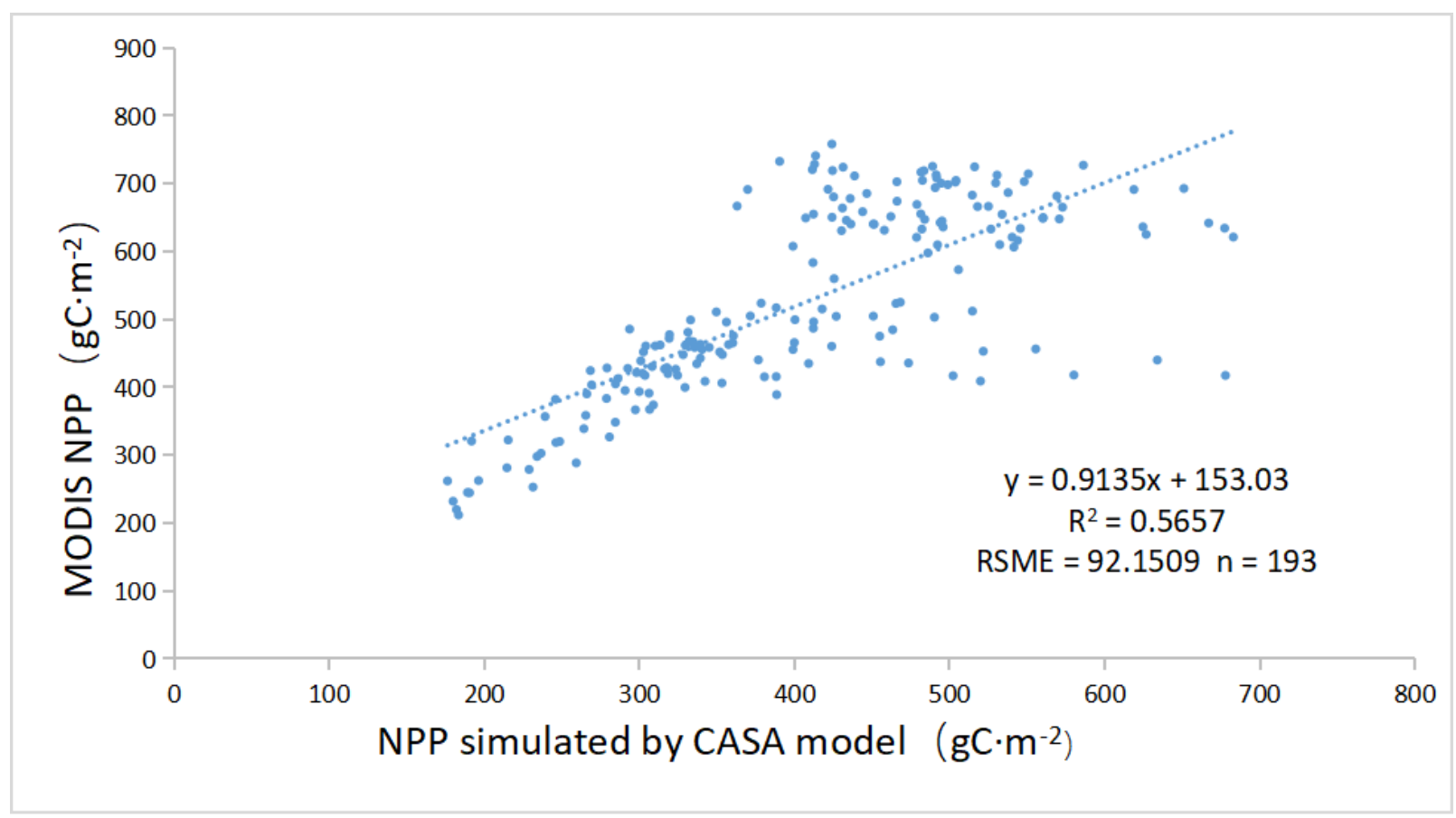

Figure A2. Comparison of NPP obtained from the CASA model and MODIS products in 2010. 


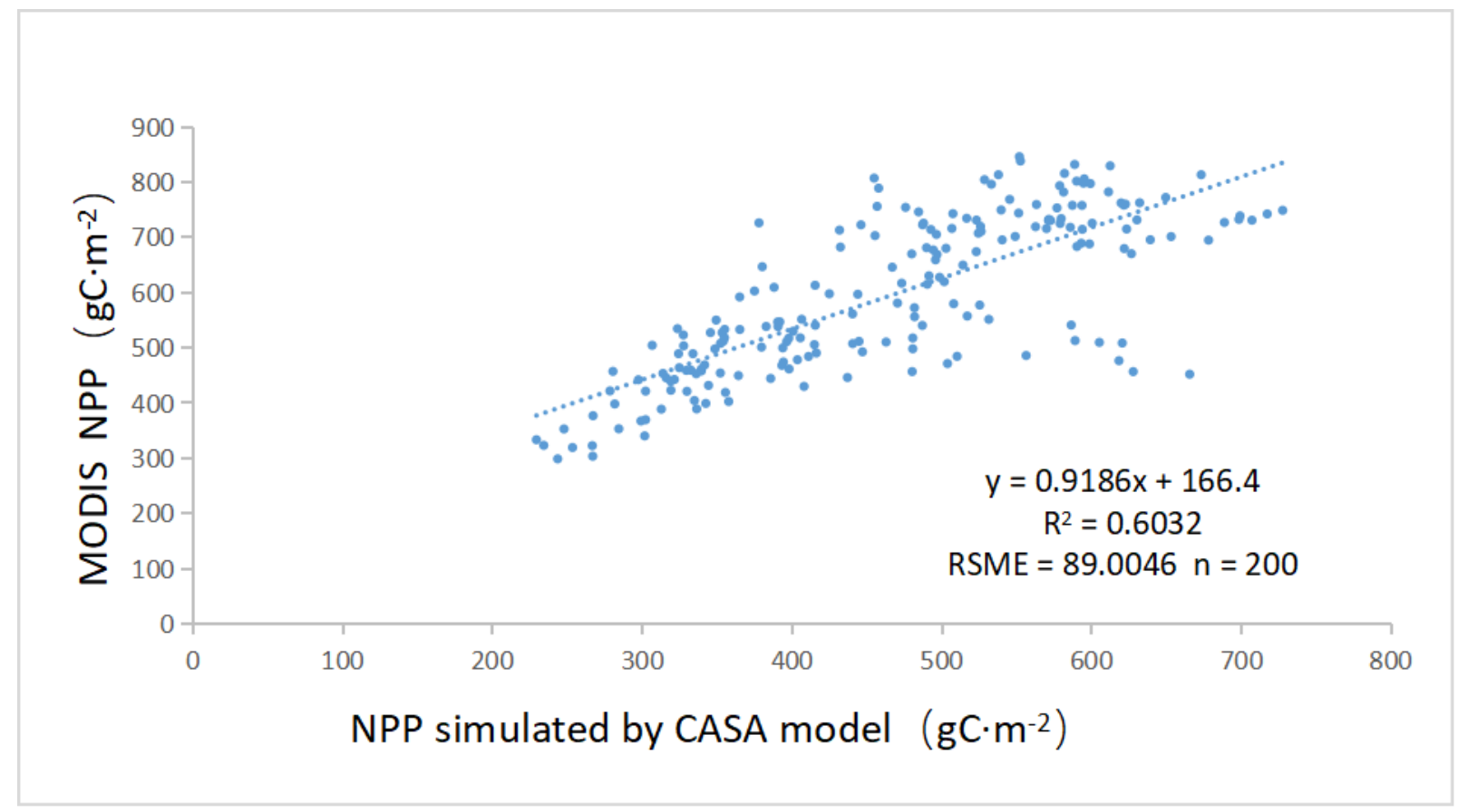

Figure A3. Comparison of NPP obtained from the CASA model and MODIS products in 2018.

Table A4. Verification results of FVC in 2000.

\begin{tabular}{cccccc}
\hline $\begin{array}{c}\text { Window } \\
\text { Number }\end{array}$ & $\begin{array}{c}\text { High-Resolution } \\
\text { Images }\end{array}$ & $\begin{array}{c}\text { Study } \\
\text { Results }\end{array}$ & $\begin{array}{c}\text { Window } \\
\text { Number }\end{array}$ & $\begin{array}{c}\text { High-Resolution } \\
\text { Images }\end{array}$ & $\begin{array}{c}\text { Study } \\
\text { Results }\end{array}$ \\
\hline 1 & 0.91 & 0.95 & 11 & 0.34 & 0.36 \\
2 & 0.98 & 0.95 & 12 & 0.89 & 0.90 \\
3 & 0.91 & 0.96 & 13 & 0.64 & 1.00 \\
4 & 0.96 & 0.83 & 14 & 1.00 & 0.99 \\
5 & 0.97 & 0.97 & 15 & 0.66 & 0.99 \\
6 & 0.98 & 1.00 & 16 & 0.69 & 0.65 \\
7 & 0.93 & 0.91 & 17 & 0.56 & 0.95 \\
8 & 0.64 & 0.91 & 18 & 0.77 & 0.95 \\
9 & 0.61 & 0.66 & 19 & 1.00 & 0.90 \\
10 & 0.70 & 0.96 & 20 & 0.70 & 0.94 \\
& Mean accuracy & & & $87.23 \%$ & \\
\hline
\end{tabular}

Table A5. Verification results of FVC in 2010.

\begin{tabular}{cccccc}
\hline $\begin{array}{c}\text { Window } \\
\text { Number }\end{array}$ & $\begin{array}{c}\text { High-Resolution } \\
\text { Images }\end{array}$ & $\begin{array}{c}\text { Study } \\
\text { Results }\end{array}$ & $\begin{array}{c}\text { Window } \\
\text { Number }\end{array}$ & $\begin{array}{c}\text { High-Resolution } \\
\text { Images }\end{array}$ & $\begin{array}{c}\text { Study } \\
\text { Results }\end{array}$ \\
\hline 1 & 0.99 & 0.96 & 12 & 0.03 & 0.13 \\
2 & 0.99 & 0.96 & 12 & 0.03 & 0.13 \\
3 & 1.00 & 0.80 & 13 & 0.81 & 1.00 \\
4 & 0.93 & 0.93 & 14 & 0.99 & 0.98 \\
5 & 0.95 & 0.99 & 15 & 0.89 & 1.00 \\
6 & 0.90 & 0.94 & 16 & 0.77 & 0.68 \\
7 & 0.98 & 1.00 & 17 & 0.66 & 1.00 \\
8 & 0.71 & 0.89 & 18 & 0.94 & 1.00 \\
9 & 0.53 & 0.68 & 19 & 1.00 & 0.96 \\
10 & 0.90 & 0.34 & 20 & 0.91 & 0.95 \\
& Mean accuracy & & & $88.47 \%$ & \\
\hline
\end{tabular}


Table A6. Verification results of FVC in 2018.

\begin{tabular}{cccccc}
\hline $\begin{array}{c}\text { Window } \\
\text { Number }\end{array}$ & $\begin{array}{c}\text { High-Resolution } \\
\text { Images }\end{array}$ & $\begin{array}{c}\text { Study } \\
\text { Results }\end{array}$ & $\begin{array}{c}\text { Window } \\
\text { Number }\end{array}$ & $\begin{array}{c}\text { High-Resolution } \\
\text { Images }\end{array}$ & $\begin{array}{c}\text { Study } \\
\text { Results }\end{array}$ \\
\hline 1 & 0.90 & 0.92 & 11 & 0.50 & 0.53 \\
2 & 0.94 & 0.98 & 12 & 0.50 & 0.47 \\
3 & 0.69 & 0.77 & 13 & 0.87 & 0.99 \\
4 & 0.97 & 0.93 & 14 & 1.00 & 1.00 \\
5 & 0.96 & 0.80 & 15 & 0.96 & 1.00 \\
6 & 0.82 & 1.00 & 16 & 0.87 & 0.81 \\
7 & 0.98 & 0.99 & 17 & 0.87 & 0.97 \\
8 & 0.74 & 0.89 & 18 & 0.96 & 0.92 \\
10 & 0.64 & 0.76 & 19 & 1.00 & 0.62 \\
& 1.00 & 1.00 & 20 & 0.93 & 0.98 \\
\hline
\end{tabular}

\section{References}

1. Chi, W.; Zhao, Y.; Kuang, W.; He, H. Impacts of anthropogenic land use/cover changes on soil wind erosion in China. Sci. Total Environ. 2019, 668, 204-215. [CrossRef] [PubMed]

2. Niraj, K.C.; Thapa, L.; Shukla, D.P. Fate of agricultural areas of Kailali District of Nepal: A temporal land use land cover change (LUCC) analysis. Int. Arch. Photogramm. Remote Sens. Spat. Inf. Sci-ISPRS 2020, 43, 1601-1606. [CrossRef]

3. Li, Z.; Sun, Z.; Tian, Y.; Zhong, J.; Yang, W. Impact of land use/cover change on yangtze river delta urban agglomeration ecosystem services value: Temporal-spatial patterns and cold/hot spots ecosystem services value change brought by urbanization. Int. J. Environ. Res. Public Health 2019, 16, 123. [CrossRef] [PubMed]

4. Msofe, N.K.; Sheng, L.; Li, Z.; Lyimo, J. Impact of land use/cover change on ecosystem service values in the Kilombero valley floodplain, southeastern Tanzania. Forests 2020, 11, 109. [CrossRef]

5. Huang, J.; Tu, Z.; Lin, J. Land-use dynamics and landscape pattern change in a coastal gulf region, southeast China. Int. J. Sustain. Dev. World Ecol. 2009, 16, 61-66. [CrossRef]

6. Fan, J.; Wang, Y.; Zhou, Z.; You, N.; Meng, J. Dynamic ecological risk assessment and management of land use in the middle reaches of the heihe river based on landscape patterns and spatial statistics. Sustainability 2016, 8, 536. [CrossRef]

7. Zhang, J.; Zhu, Y.; Fan, F. Mapping and evaluation of landscape ecological status using geographic indices extracted from remote sensing imagery of the Pearl River Delta, China, between 1998 and 2008. Environ. Earth Sci. 2016, 75, 1-16. [CrossRef]

8. Ying, X.; Zeng, G.M.; Chen, G.Q.; Tang, L.; Wang, K.L.; Huang, D.Y. Combining AHP with GIS in synthetic evaluation of eco-environment quality-A case study of hunan province, China. Ecol. Modell. 2007, 209, 97-109. [CrossRef]

9. Tayyebi, A.; Perry, P.C.; Tayyebi, A.H. Predicting the expansion of an urban boundary using spatial logistic regression and hybrid raster-vector routines with remote sensing and GIS. Int. J. Geogr. Inf. Sci. 2014, 28, 639-659. [CrossRef]

10. Pijanowski, B.C.; Tayyebi, A.; Doucette, J.; Pekin, B.K.; Braun, D.; Plourde, J. A big data urban growth simulation at a national scale: Configuring the GIS and neural network based land transformation model to run in a high performance computing (HPC) environment. Environ. Model. Softw. 2014, 51, 250-268. [CrossRef]

11. Song, W.; Liu, M. Assessment of decoupling between rural settlement area and rural population in China. Land Use Policy 2014, 39, 331-341. [CrossRef]

12. Uchida, E.; Xu, J.; Rozelle, S. Grain for green: Cost-effectiveness and sustainability of China's conservation set-aside program. Land Econ. 2003, 81, 247-264. [CrossRef]

13. Zhou, J.; Xu, Y.; Gao, Y.; Xie, Z. Land use model research in agro-pastoral ecotone in northern China: A case study of horqin left back banner. J. Environ. Manag. 2019, 237, 139-146. [CrossRef]

14. Adhikari, A.; Hansen, A.J. Land use change and habitat fragmentation of wildland ecosystems of the North Central United States. Landsc. Urban Plan. 2018, 177, 196-216. [CrossRef]

15. Hu, Y.; Nacun, B. An analysis of land-use change and grassland degradation from a policy perspective in Inner Mongolia, China, 1990-2015. Sustainability 2018, 10, 4048. [CrossRef]

16. Loveland, T.R.; Belward, A.S. The igbp-dis global $1 \mathrm{~km}$ land cover data set, discover: First results. Int. J. Remote Sens. 1997, 18, 3289-3295. [CrossRef]

17. Hansen, M.C.; Sohlberg, R.; Defries, R.S.; Townshend, J.R.G. Global land cover classification at $1 \mathrm{~km}$ spatial resolution using a classification tree approach. Int. J. Remote Sens. 1997, 18, 3289-3295. [CrossRef]

18. Bartholomé, E.; Belward, A.S. GLC2000: A new approach to global land cover mapping from earth observation data. Int. J. Remote Sens. 2005, 26, 1959-1977. [CrossRef]

19. Friedl, M.A.; Sulla-Menashe, D.; Tan, B.; Schneider, A.; Ramankutty, N.; Sibley, A.; Huang, X. MODIS Collection 5 global land cover: Algorithm refinements and characterization of new datasets. Remote Sens. Environ. 2010, 114, 168-182. [CrossRef] 
20. Defourny, P.; Vancutsem, C.; Bicheron, C.; Brockmann, C.; Nino, F.; Schouten, L.; Leroy, M. GlobCover: A 300M global land cover product for 2005 using envisat meris time series. using Envisat MERIS time series. In Proceedings of the ISPRS Commission VII Mid-Term Symposium, Remote Sensing from Pixels to Processes, Enschede, The Netherlands, 8-11 May 2006; pp. 8-11.

21. Jin, S.; Homer, C.; Yang, L.; Danielson, P.; Dewitz, J.; Li, C.; Zhu, Z.; Xian, G.; Howard, D. Overall methodology design for the United States national land cover database 2016 products. Remote Sens. 2019, 11, 2971. [CrossRef]

22. Gong, P.; Wang, J.; Yu, L.; Zhao, Y.; Zhao, Y.; Liang, L.; Niu, Z.; Huang, X.; Fu, H.; Liu, S.; et al. Finer resolution observation and monitoring of global land cover: First mapping results with Landsat TM and ETM+ data. Int. J. Remote Sens. 2013, 34, $2607-2654$. [CrossRef]

23. Liu, H.; Zhang, Y.; Zhang, X. Monitoring vegetation coverage in tongren from 2000 to 2016 based on landsat7 etm + and landsat8. An. Acad. Bras. Cienc. 2018, 90, 2721-2730. [CrossRef]

24. Alton, P.B. Representativeness of global climate and vegetation by carbon-monitoring networks; implications for estimates of gross and net primary productivity at biome and global levels. Agric. For. Meteorol. 2020, 290, 108017. [CrossRef]

25. Chang, S.; Wang, J.; Zhang, F.; Niu, L.; Wang, Y. A study of the impacts of urban expansion on vegetation primary productivity levels in the Jing-Jin-Ji region, based on nighttime light data. J. Clean. Prod. 2020, 263, 121490. [CrossRef]

26. Xiao, J.; Moody, A. A comparison of methods for estimating fractional green vegetation cover within a desert-to-upland transition zone in central New Mexico, USA. Remote Sens. Environ. 2005, 98, 237-250. [CrossRef]

27. Potter, S.; Randerson, T.; Field, B.; Matson, A.; Mooney, H.A. Terrestrial ecosystem production-A process model based on global satellite and surface data. Glob. Biogeochem. Cycles 1993, 7, 811-841. [CrossRef]

28. Veroustraete, F.; Sabbe, H.; Eerens, H. Estimation of carbon mass fluxes over Europe using the C-fix model and Euroflux data Remote Sens. Environ. 2002, 83, 376-399. [CrossRef]

29. Cao, F.; Li, J.; Fu, X.; Wu, G. Impacts of land conversion and management measures on net primary productivity in semi-arid grassland. Ecosyst. Health Sustain. 2020, 6, 6. [CrossRef]

30. Bao, G.; Tuya, A.; Bayarsaikhan, S.; Dorjsuren, A.; Mandakh, U.; Bao, Y.; Li, C.; Vanchindorj, B. Variations and climate constraints of terrestrial net primary productivity over Mongolia. Quat. Int. 2020, 537, 112-125. [CrossRef]

31. Gu, Z.; Ju, W.; Li, L.; Li, D.; Liu, Y.; Fan, W. Using vegetation indices and texture measures to estimate vegetation fractional coverage (VFC) of planted and natural forests in Nanjing city, China. Adv. Sp. Res. 2013, 51, 1186-1194. [CrossRef]

32. Li, S.; Wang, J.; Zhang, M.; Tang, Q. Characterizing and attributing the vegetation coverage changes in North Shanxi coal base of China from 1987 to 2020. Resour. Policy 2021, 74, 102331. [CrossRef]

33. Zhang, L.; Qiao, N.; Hasan, M.; Baig, A.; Huang, C.; Lv, X. Monitoring vegetation dynamics using the universal normalized vegetation index (UNVI): An optimized vegetation index-VIUPD. Remote Sens. Lett. 2019, 10, 629-638. [CrossRef]

34. Wang, R.; Yan, F.; Wang, Y. Vegetation growth status and topographic effects in the pisha sandstone area of China. Remote Sens. 2020, 12, 2759. [CrossRef]

35. Li, P.; He, Z.; He, D.; Xue, D.; Wang, Y.; Cao, S. Fractional vegetation coverage response to climatic factors based on grey relational analysis during the 2000-2017 growing season in Sichuan Province, China. Int. J. Remote Sens. 2020, 41, 1170-1190. [CrossRef]

36. Gong, P.; Chen, B.; Li, X.; Liu, H.; Wang, J.; Bai, Y.; Chen, J.; Chen, X.; Fang, L.; Feng, S.; et al. Mapping essential urban land use categories in China (EULUC-China): Preliminary results for 2018. Sci. Bull. 2020, 65, 182-187. [CrossRef]

37. Bayr, U.; Puschmann, O. Automatic detection of woody vegetation in repeat landscape photographs using a convolutional neural network. Ecol. Inform. 2019, 50, 220-233. [CrossRef]

38. Gong, P.; Liu, H.; Zhang, M.; Li, C.; Wang, J.; Huang, H.; Clinton, N.; Ji, L.; Li, W.; Bai, Y.; et al. Stable classification with limited sample: Transferring a 30-m resolution sample set collected in 2015 to mapping 10-m resolution global land cover in 2017. Sci. Bull. 2019, 64, 370-373. [CrossRef]

39. Litjens, G.; Kooi, T.; Bejnordi, B.E.; Setio, A.A.A.; Ciompi, F.; Ghafoorian, M.; van der Laak, J.A.W.M.; van Ginneken, B.; Sánchez, C.I. A survey on deep learning in medical image analysis. Med. Image Anal. 2017, 42, 60-88. [CrossRef]

40. Krizhevsky, B.A.; Sutskever, I.; Hinton, G.E. ImageNet classification with deep convolutional neural networks. Commun. ACM 2017, 60, 84-90. [CrossRef]

41. Unnikrishnan, A.; Sowmya, V.; Soman, K.P. Deep alexnet with reduced number of trainable parameters for satellite image classification. Procedia Comput. Sci. 2018, 143, 931-938. [CrossRef]

42. Blaschke, T. Object based image analysis for remote sensing. ISPRS J. Photogramm. Remote Sens. 2010, 65, 2-16. [CrossRef]

43. Chen, Y.; Qiang, Z.; Chen, X.; Liu, X. Classifition of land use scenarios based on find-tuing convolution naturel network. Remote Sens. Inf. 2019, 34, 70-77.

44. Koju, U.A.; Zhang, J.; Maharjan, S.; Bai, Y.; Zhang, S.; Yao, F. Analysis of spatiotemporal dynamics of forest net primary productivity of Nepal during 2000-2015. Int. J. Remote Sens. 2020, 41, 4336-4364. [CrossRef]

45. Jin, H.; Bao, G.; Chen, J.; Chopping, M.; Jin, E.; Mandakh, U.; Jiang, K.; Huang, X.; Bao, Y.; Vandansambuu, B. Modifying the maximal light-use efficiency for enhancing predictions of vegetation net primary productivity on the Mongolian Plateau. Int. J. Remote Sens. 2020, 41, 3740-3760. [CrossRef]

46. Li, J.; Zhou, K.; Chen, F. Drought severity classification based on threshold level method and drought effects on NPP. Theor. Appl. Climatol. 2020, 142, 675-686. [CrossRef]

47. Pei, Y.; Huang, J.; Wang, L.; Chi, H.; Zhao, Y. An improved phenology-based CASA model for estimating net primary production of forest in central China based on Landsat images. Int. J. Remote Sens. 2018, 39, 7664-7692. [CrossRef] 
48. Zhu, W.; Pan, Y.; He, H.; Yu, D.; Hu, H. Simulation of maximum light use efficiency for some typical vegetation types in China. Chin. Sci. Bull. 2006, 51, 457-463. [CrossRef]

49. Boyd, D.S.; Foody, G.M.; Ripple, W.J. Evaluation of approaches for forest cover estimation in the Pacific Northwest, USA, using remote sensing. Appl. Geogr. 2002, 22, 375-392. [CrossRef]

50. Liu, Q.; Zhang, T.; Li, Y.; Li, Y.; Bu, C.; Zhang, Q. Comparative analysis of fractional vegetation cover estimation based on multi-sensor data in a semi-arid sandy area. Chin. Geogr. Sci. 2019, 29, 166-180. [CrossRef]

51. Gitelson, A.A.; Stark, R.; Rundquist, D.; Gitelson, A.A.; Kaufman, Y.J.; Stark, R.; Rundquist, D. Novel algorithms for remote estimation of vegetation fraction. Remote Sens. Environ. 2002, 80, 76-87. [CrossRef]

52. Jia, K.; Li, Y.; Liang, S.; Wei, X.; Yao, Y. Combining estimation of green vegetation fraction in an arid region from Landsat 7 ETM+ data. Remote Sens. 2017, 9, 1121. [CrossRef]

53. Jing, Y.; Zhang, F.; He, Y.; Kung, H.T.; Johnson, V.C.; Arikena, M. Assessment of spatial and temporal variation of ecological environment quality in Ebinur lake Wetland National Nature Reserve, Xinjiang, China. Ecol. Indic. 2020, 110, 105874. [CrossRef]

54. Rihan, W.; Zhao, J.; Zhang, H.; Guo, X.; Ying, H.; Deng, G.; Li, H. Wildfires on the Mongolian Plateau: Identifying drivers and spatial distributions to predict wildfire probability. Remote Sens. 2019, 11, 2361. [CrossRef]

55. Gao, Q.; Schwartz, M.W.; Zhu, W.; Wan, Y.; Qin, X.; Ma, X.; Liu, S.; Williamson, M.A.; Peters, C.B.; Li, Y. Changes in global grassland productivity during 1982 to 2011 attributable to climatic factors. Remote Sens. 2016, 8, 384. [CrossRef]

56. Bao, G.; Liu, Y.; Liu, N.; Linderholm, H.W. Drought variability in eastern Mongolian Plateau and its linkages to the large-scale climate forcing. Clim. Dyn. 2015, 44, 717-733. [CrossRef]

57. Wang, R.; Yang, L. The research of livestock carrying capacity of rangeland ecosystem in HulunBuir. Adv. Mater. Res. 2012, 365, 110-114. [CrossRef]

58. Fang, H.; Fan, Z. Assessment of soil erosion at multiple spatial scales following land use changes in $1980-2017$ in the black soil region, (NE) China. Int. J. Environ. Res. Public Health 2020, 17, 7378. [CrossRef]

59. Na, R.; Du, H.; Na, L.; Shan, Y.; He, H.S.; Wu, Z.; Zong, S.; Yang, Y.; Huang, L. Spatiotemporal changes in the Aeolian desertification of Hulunbuir Grassland and its driving factors in China during 1980-2015. Catena 2019, 182, 104123. [CrossRef]

60. Hao, L.; Sun, G.; Liu, Y.; Gao, Z.; He, J.; Shi, T.; Wu, B. Effects of precipitation on grassland ecosystem restoration under grazing exclusion in Inner Mongolia, China. Landsc. Ecol. 2014, 29, 1657-1673. [CrossRef]

61. Wang, Y.; Zhang, J.; Tong, S.; Guo, E. Monitoring the trends of aeolian desertified lands based on time-series remote sensing data in the Horqin Sandy Land, China. Catena 2017, 157, 286-298. [CrossRef]

62. Wang, Z.; Wang, Z.; Zhang, B.; Lu, C.; Ren, C. Landscape dynamics in Hulunbuir Grassland of China. In Proceedings of the International Conference on Remote Sensing, Environment and Transportation Engineering (RSETE), Nanjing, China, 316-319., 26-28 July 2013; pp. 316-319. [CrossRef]

63. Wang, Z.; Zhong, J.; Lan, H.; Wang, Z.; Sha, Z. Association analysis between spatiotemporal variation of net primary productivity and its driving factors in inner mongolia, china during 1994-2013. Ecol. Indic. 2019, 105, 355-364. [CrossRef]

64. Gupta, K.; Kumar, P.; Pathan, S.K.; Sharma, K.P. Urban neighborhood green index-A measure of green spaces in urban areas. Landsc. Urban Plan. 2012, 105, 325-335. [CrossRef]

65. Sun, C.M.; Zhong, X.C.; Chen, C.; Gu, T.; Chen, W. Evaluating the grassland net primary productivity of southern China from 2000 to 2011 using a new climate productivity model. J. Integr. Agric. 2016, 15, 1638-1644. [CrossRef]

66. Zhao, Y.; Liu, H.; Zhang, A.; Cui, X.; Zhao, A. Spatiotemporal variations and its influencing factors of grassland net primary productivity in Inner Mongolia, China during the period 2000-2014. J. Arid Environ. 2019, 165, 106-118. [CrossRef]

67. Chen, Y.; Gao, J.; Feng, C.; Jia, X. Temporal and spatial distribution of vegetation net primary productivity (NPP) in the Years from 1982 to 2010 in Hulunbeier. J. Ecol. Rural Environ. 2012, 8, 647-653.

68. Mao, D.; Wang, Z.; Wu, C.; Song, K.; Ren, C. Examining forest net primary productivity dynamics and driving forces in northeastern China during 1982-2010. Chin. Geogr. Sci. 2014, 24, 631-646. [CrossRef]

69. Cao, X.; Wang, J.; Gao, Z.; Ning, J.; Shi, R.; Gao, W. Study on spatio-temporal vegetation cover changes based on MODIS NDVI data in the Mongolian Plateau, 2000-2012. Remote Sens. Model. Ecosyst. Sustain. X 2013, 8869, 88690Z. [CrossRef]

70. Wei, X.; Wang, S.; Wang, Y. Spatial and temporal change of fractional vegetation cover in North-western China from 2000 to 2010. Geol. J. 2018, 53, 427-434. [CrossRef]

71. Peng, F.; Fan, W.; Xu, X.; Liu, X. Analysis on temporal-spatial change of vegetation coverage in hulunbuir steppe (2000-2014) Presented at the IEEE International Geoscience and Remote Sensing Symposium (IGARSS). Beijing Daxue Xuebao (Ziran Kexue Ban) 2017, 53, 563-572. [CrossRef]

72. Li, F.; Chen, W.; Zeng, Y.; Zhao, Q.; Wu, B. Improving estimates of grassland fractional vegetation cover based on a pixel dichotomy model: A case study in Inner Mongolia, China. Remote Sens. 2014, 6, 4705-4722. [CrossRef]

73. Peng, S.; Piao, S.; CIAIS, P.; Fang, J.; Wang, X. Change in winter snow depth and its impacts on vegetation in China. Glob. Change Biol. 2010, 16, 3004-3013. [CrossRef]

74. Liu, H.; Ma, L. Spatial pattern and effects of urban coordinated development in China's urbanization. Sustainability 2020, 12, 2389. [CrossRef]

75. Wang, Q.; Li, Y.; Luo, G. Spatiotemporal change characteristics and driving mechanism of slope cultivated land transition in karst trough valley area of Guizhou Province, China. Environ. Earth Sci. 2020, 79, 1-18. [CrossRef] 
76. Wolfe, S.A.; Hugenholtz, C.H. Barchan dunes stabilized under recent climate warming on the northern Great Plains. Geology 2009, 37, 1039-1042. [CrossRef]

77. Liu, J.; Kuang, W.; Zhang, Z.; Xu, X.; Qin, Y.; Ning, J.; Zhou, W.; Zhang, S.; Li, R.; Yan, C.; et al. Spatiotemporal characteristics, patterns, and causes of land-use changes in China since the late 1980s. J. Geogr. Sci. 2014, 24, 195-210. [CrossRef] 